\title{
Characterization of Volume F trash from four recent STS missions: weights, categorization, water content
}

\author{
Richard F. Strayer, ${ }^{1}$ Mary E. Hummerick, ${ }^{2}$ Jeffrey T. Richards, ${ }^{3}$ LaShelle E. McCoy, ${ }^{4}$ Michael S. Roberts ${ }^{5}$ \\ Dynamac Corporation, Kennedy Space Center, FL, 32899 \\ and \\ Raymond M. Wheeler ${ }^{6}$ \\ Surface Systems Division, Kennedy Space Center, FL, 32899
}

\begin{abstract}
The fate of space-generated solid wastes, including trash, for future missions is under consideration by NASA. Several potential treatment options are under consideration and active technology development. Potential fates for space-generated solid wastes are: Storage without treatment; storage after treatment(s) including volume reduction, water recovery, sterilization, and recovery plus recycling of waste materials. Recyling might be important for partial or full closure scenarios because of the prohibitive costs associated with resupply of consumable materials. For this study, we determined the composition of trash returned from four recent STS missions. The trash material was 'Volume F' trash and other trash, in large zip-lock bags, that accompanied the Volume $F$ trash. This is the first of two submitted papers on these wastes. This one will cover trash content, weight and water content. The other will report on the microbial characterization of this trash. STS trash was usually made available within 2 days of landing at KSC. The Volume F bag was weighed, opened and the contents were catalogued and placed into one of the following categories: food waste (and containers), drink containers, personal hygiene items - including EVA maximum absorbent garments (MAGs)and Elbow packs (daily toilet wipes, etc), paper, and packaging materials - plastic film and duct tape. Trash generation rates for the four STS missions: Total wet trash was $0.602 \pm 0.089 \mathrm{~kg}_{\text {wet }} \mathrm{crew}^{-1} \mathrm{~d}^{-1}$ containing about $25 \%$ water at $0.154 \pm$ $0.030 \mathrm{~kg}_{\text {water }} \mathrm{crew}^{-1} \mathrm{~d}^{-1}$ (avg \pm stdev). Cataloguing by category: personal hygiene wastes accounted for $50 \%$ of the total trash and $\mathbf{6 9 \%}$ of the total water for the four missions; drink items were $16 \%$ of total weight and $16 \%$ water; food wastes were $22 \%$ of total weight and $15 \%$ of the water; office waste and plastic film were $2 \%$ and $11 \%$ of the total waste and did not contain any water. The results can be used by NASA to determine requirements and criteria for Waste Management Systems on future missions.
\end{abstract}

\section{Nomenclature}

$\begin{array}{ll}\text { STS } & =\text { U.S. Space Transport System, i.e., the shuttle. } \\ K S C & =\text { Kennedy Space Center, FL, USA. } \\ E V A & =\text { Extra Vehicular Activity, i.e., space walks while in orbit } \\ W M S & =\text { Waste Management Systems element } \\ C y & =\text { force coefficient in the } y \text { direction } \\ c & =\text { chord }\end{array}$

\footnotetext{
${ }_{1}^{1}$ Research Scientist Sustainable Systems Research, Mail Code ESC-53, Kennedy Space Center, FL 32899.

${ }^{2}$ Research Scientist Sustainable Systems Research, Mail Code ESC-53, Kennedy Space Center, FL 32899.

${ }^{3}$ Research Scientist Sustainable Systems Research, Mail Code ESC-53, Kennedy Space Center, FL 32899.

${ }^{4}$ Research Scientist Sustainable Systems Research, Mail Code ESC-53, Kennedy Space Center, FL 32899.

${ }^{5}$ Research Scientist Sustainable Systems Research, Mail Code ESC-53, Kennedy Space Center, FL 32899.

${ }^{6}$ Senior Scientist, Surface Systems Division, Mạil Code NE-S, Kennedy Space Center, FL 32899.
}

1

American Institute of Aeronautics and Astronautics 


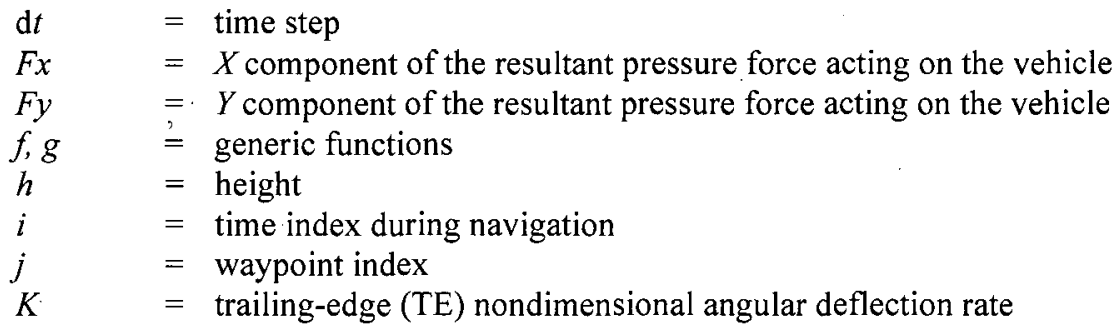

\section{Introduction}

THE Waste Management Systems (WMS) element of the Life Support and Habitation Systems program is responsible for the development of technologies and approaches to manage the numerous types of solid waste materials generated in future human space flight. Currently, STS and ISS utilize simple waste management methods, where trash is stored, and either burned during Earth reentry (Russian Progress vehicles) or returned to Earth (STS). Future long-duration missions will require more sophisticated methods for in-situ processing, storage and disposal of wastes. The WMS element is therefore engaged in designing, developing and testing technologies that: ensure the protection of the health and well-being of the crew; optimize waste storage volume; minimize crew handling; recover resources; and meet planetary protection guidelines.

WMS has a number of solid waste treatment technologies that are, or have been, under development. The goals of these treatments are to (1) reduce the volume of the waste because storage space is very limited on space vehicles, (2) the remove and recover water because many wastes contain water and easily biodegraded organic compounds from food wastes and crew feces, (3) stabilize and make wastes safe for the crew and harmless to the environment, (4) contain waste to isolate it from the crew and the rest of the world, and dispose of the contained waste, and (5) process the waste for reuse of resources within the stored waste. Because a major reason behind goals (2), (3), and (4) are to eliminate hazards to crew caused by the presence of pathogenic or otherwise deleterious microorganisms in solid wastes, our efforts at KSC have been to provide support to WMS process technologies that have been designed to eliminate microbiological hazards. These technologies have been selected because they either remove and recover water, which microbes need to survive and grow, or they sterilize the solid waste, usually though heat.

The role of our support projects at KSC have been to characterize the microflora present in space-generated solid wastes such as food wastes, crew fecal wastes, and other wet organic wastes. These wastes typically contain easily biodegraded organic compounds that support microbial growth and proliferation. If solid wastes remain untreated or unprocessed and are then placed into storage, over time the labile organic components in the waste will likely be responsible for both microbial proliferation and microbial byproduct production of noxious odors.

Two studies at KSC in FY07 and FY08, respectively, have examined the microbial characterization of food wastes in simulated space mission trash, i.e., for a Lunar Base. However, the wastes were inoculated with saliva collected from volunteer donors after a vigorous mouth scrubbing with sterile swabs. Volunteer body wipes, in lieu of a shower, disinfectant and wet wipes of facility urinals and commodes, and dry wipes of laboratory tabletop surfaces were also added to the simulated waste after placing the wipes into a ziplock bags, which were then sealed. At the time, we felt that these inocula would 'simulate' what the wastes were inoculated with in a space habitat. However, the results of the study indicated that few human pathogens were present in the wastes, thus we wondered if the inocula might not be very representative. During these studies, we had access to the wet waste from the Volume F trash returned on each STS mission, but resources were not available to process these wastes for our microbiological studies. This all changed this past year as both access and resources could be used.

Although our primary goal was microbial characterization of the STS Volume F trash, we also had the opportunity to characterize, or survey, the contents of the trash in relation to total wet weights, water content, plastic film content, and to photodocument the trash contents. This paper reports our findings on this physical characterization of the Volume $\mathrm{F}$ trash from four recent shuttle missions. A second paper for this conference reports our results of the microbiological characterization of this trash (reference).

\section{Materials and Methods}

\section{A. Approach}

Voume $\mathrm{F}$ wet trash and other large ziplock plastic bags, which also contained trash items, are generated on each STS mission, whether to the International Space Station (ISS) or not.. As noted by Kish, et al. ${ }^{1}$, waste storage aboard the orbiter consists of the Volume F compartment for wet treash and includes mealtime wastes such as leftover food 
and drink and the associated food packaging, personal hygiene articles, toilet wipes (termed "elbow packs" because of their shape), and Maximum Adsorption Garments (MAGs) worn by the crew during launch and extravehicular activities (EVA). The Volume F trash from four recent STS missions were available for this report and mission specifics are shown in Table 1.

\begin{tabular}{|c|c|c|c|c|}
\hline Shttle Mission & Crew Size, & Launch Date & Landing Date & Mission duration \\
\hline STS 129 & 6 & 16-Nov-09 & 27-Nov-09 & 10 days, 19 hours, 16 minutes, 13 seconds \\
\hline STS 130 & 6 & $08-F e b-10$ & $21-F e b-10$ & 13 days, 18 hours, 6 minutes, 24 seconds \\
\hline STS 131 & 7 & $05-A p r-10$ & $20-A p r-10$ & 15 days, 2 hours, 47 minutes, 10 seconds \\
\hline STS 132 & 6 & 14-May-10 & 26-May-10 & 11 days, 18 hours, 29 minutes, 9 seconds \\
\hline
\end{tabular}

\section{B. Sequence of sampling events for each shuttle landing at KSC}

Upon notification by shuttle personnel, usually withing 48 hours of landing, the Volume $\mathrm{F}$ trash waste was picked up from landing support personnel. Trash was stored at room temperature, between 1 and 3 days, before it could be processed and characterized. Processing and characterization, including microbial characterization from sample acquisition to dilutions to inoculation of enumeration media, usually took 2 to 3 work days.

First, total wet weight was determined of the entire Volume F trash and any accompanying large zip-lock bags of trash. The Volume F trash bag and accompanying bags were next opened and the contents were cataloged and photographed. The contents were smaller plastic liner bags, termed 'footballs' by former STS crews, that had been closed by wrapping them with duct tape. Footballs that contained what looked like food trash, drink pouches, or personal hygiene items were aseptically cut open and the contents were sorted and placed into categories. Footballs that obviously contained MAGs or elbow packs, i.e., toilet wipes, were not opened at this time, but placed into these categories. Next, the total wet weight of each category was determined and subsamples were taken, aseptically for microbiological analyses and some for dry weight determinations $\left(70^{\circ} \mathrm{C}\right.$ until dry, usually overnight). During the physical categorization and opening of footballs, outer plastic bags and duct tape were placed into the plastic and packaging category to determine a total weight of this category.

\section{Results and Discussion}

\section{A. Separation, cataloging, and sampling of STS wet trash.}

Photos 1 through 8 show some of the representative pictures taken during the process of opening the trash bags and cataloging and categorizing the trash items. The main trash bag, the Volume $\mathrm{F}$ trash is shown in Photo 1 . This bag was made of a very thick film plastic that appears to contain all trash generated while the shuttle was in orbit and while attached to the ISS. As can be seen through the semi-trasparent plastic, the Volume $\mathrm{F}$ trash contains individual 'footballs' of the various trash items. The term apparently comes from early STS crews which thought the shapes of these resembles the sahpe of American footballs. Each football contained items that had been placed in smaller plastic bags, or liners, that had been closed by wrapping with silver duct tape. After the outer Volume $\mathrm{F}$ bag was opened, the contents were catalogued and placed into categories that were defined as the cataloguing process proceeded (Photo 3, Photo 4). In addition to the thick plastic film Volume F bag, there were separate, large ziplock plastic bags (Photo 2). These were not labeled so we called them Bag A, Bag B, or Bag C. Different shuttle missions had different numbers of these additional trash-containing bags. For STS 129 there was one of these, Bag A, for STS 130 there were three (A, B, and C), for STS 131 there were two (A and B), and for STS 132 there were three (A, B, and $C$ ). From the contents of these bags we deduced they might be trash items that were accumulated before and after docking with the ISS, i.e., between launch and docking with the ISS or between undocking from ISS and before landing. Food items in these bags were mostly snack items than the full meal items found in the Volume $\mathrm{F}$ trash.

Photos 5, 6, and 7 are all 'footballs' found in the Volume F trash. They were separately placed into plastic-film ziplock bags, and securely wrapped with duct tape. Some had duct tape wrapped around the middle both longitudinally and laterally, while others were completely covered with a layer of duct tape. After opening and examining the contents of a few of these footballs, we could usually differentiate between footballs without opening them. The categories we labeled these footballs were: food (and like items) footballs (Photo 5), MAG (EVA diapers) footballs (Photo 6), and Elbow pack (daily toilet wipes, etc.) footballs (Photo 7). The contents of one Elbow pack football is shown in Photo 8. The food footballs contained heterogenous wastes (non-MAG or Elbow Pack wastes), 
including drinks, food waste items and packaging, personal hygiene wastes such as wipes, and paper / office items. Photo 9 shows a bin with items we categorized as personal hygiene items, i.e., wipes, and paper, etc., that were removed from a number of food waste (predominantly) footballs. The only other photodocumentation of Volume $\mathrm{F}$ trash was done by Kish, et al. ${ }^{1}$, and these digital images are still available. The photos of trash from STS 105, taken in 2001, do not appear very different from the trash photos shown here for STS 129.

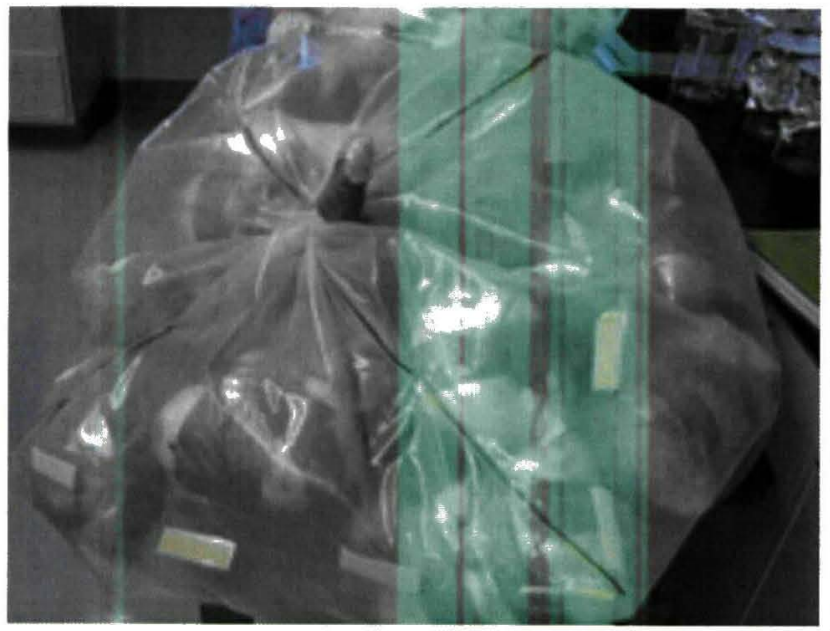

Photo 1. Shuttle Volume F trash.

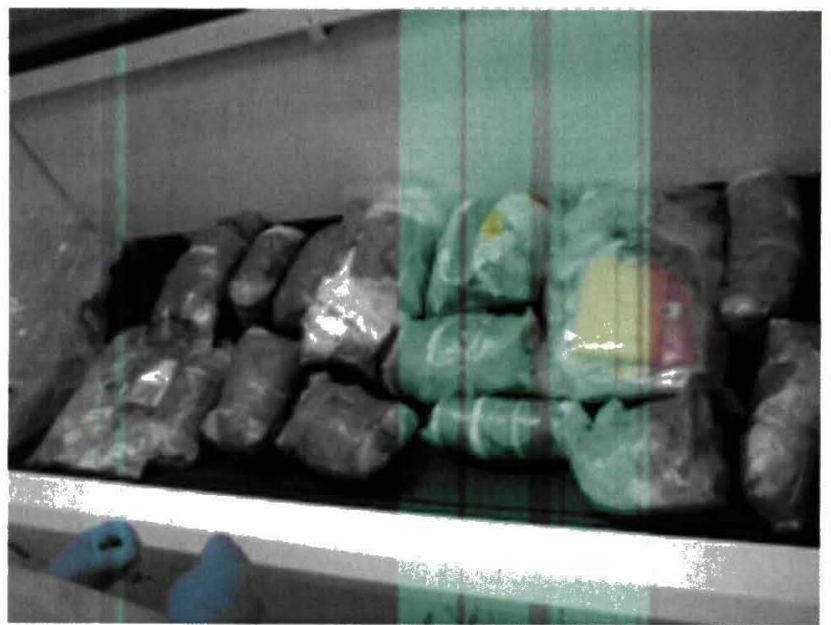

Photo 3. Mixture of different football types prior to cataloguing and placeing into categories. Footballs are from the Shuttle Volume F trash.

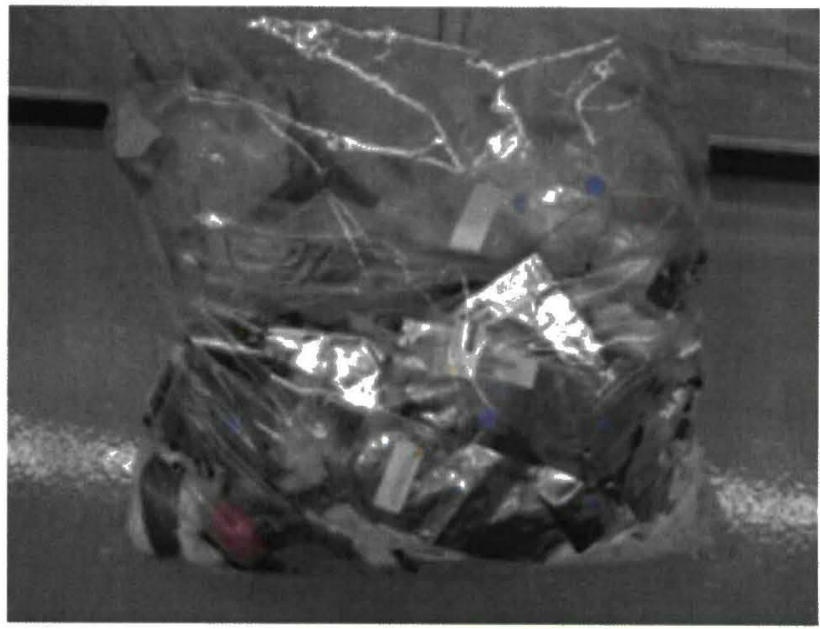

Photo 2. Shuttle trash, not Volume F trash, contained in a large ziplock plastic film bag.

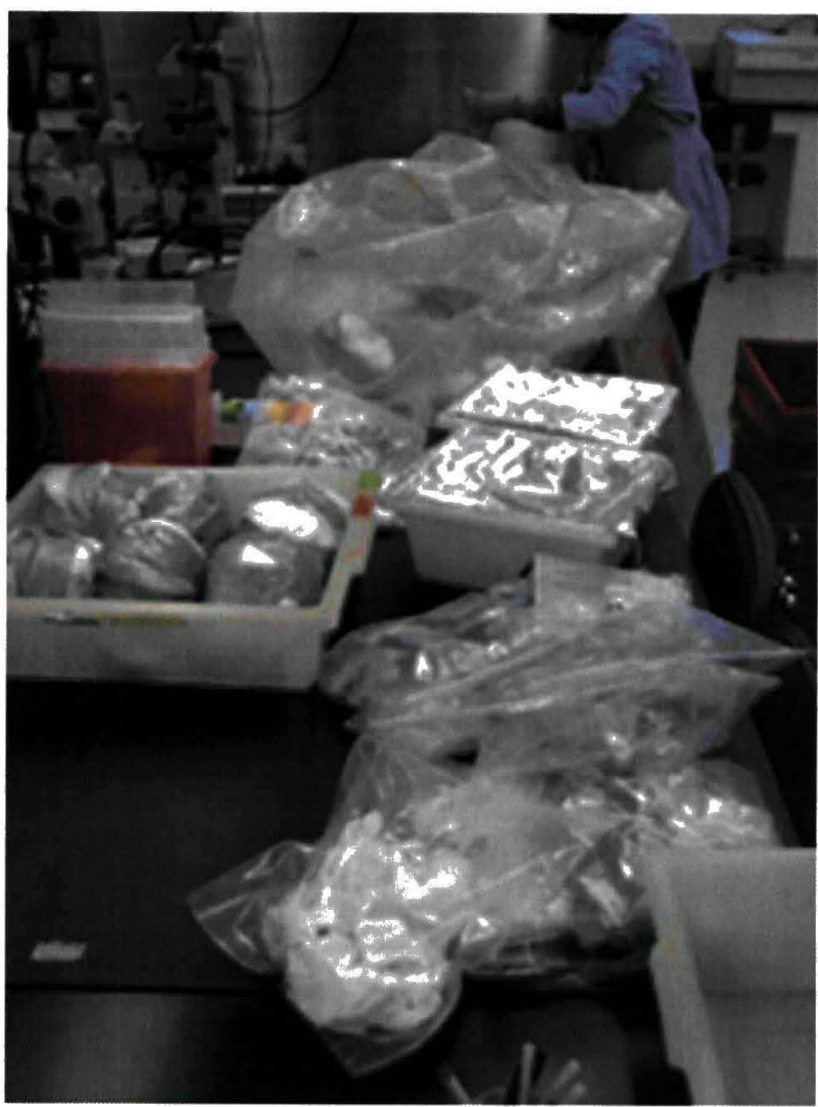

Photo 4. Project personnel cataloguing and categorizing football contents. The footballs were from the Shuttle Volume F trash. 


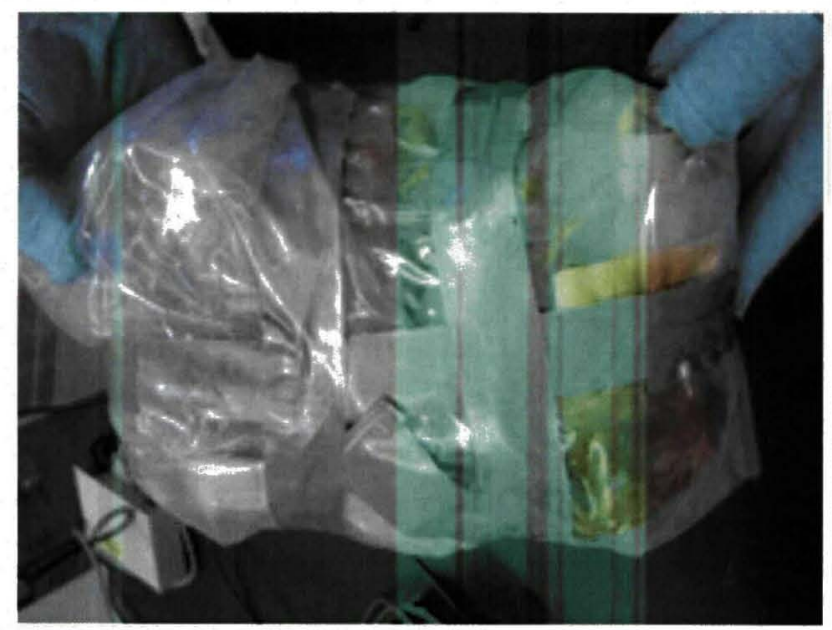

Photo 5. A food 'football' from the Shuttle Volume F trash.

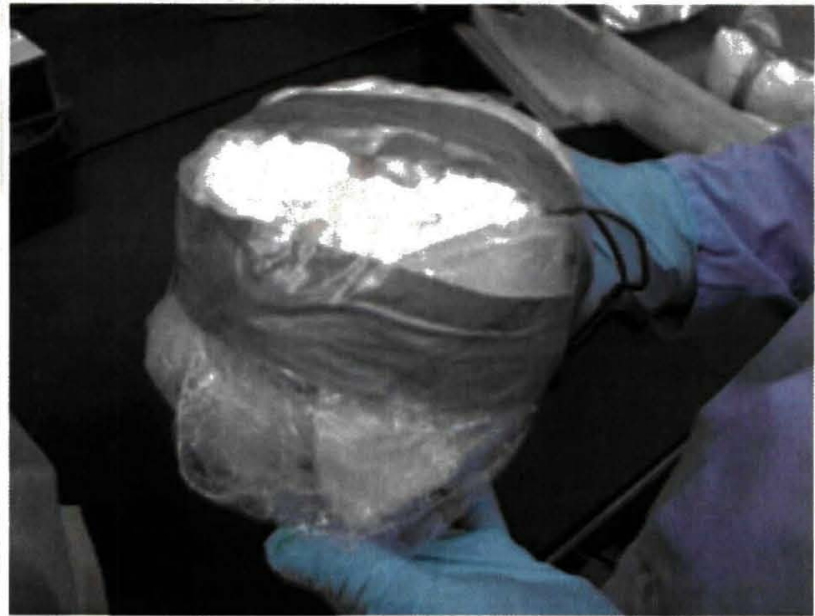

Photo 6. A Maximum Adsorption Garment (MAG, EVA diaper) 'football' from the Shuttle Volume F trash.

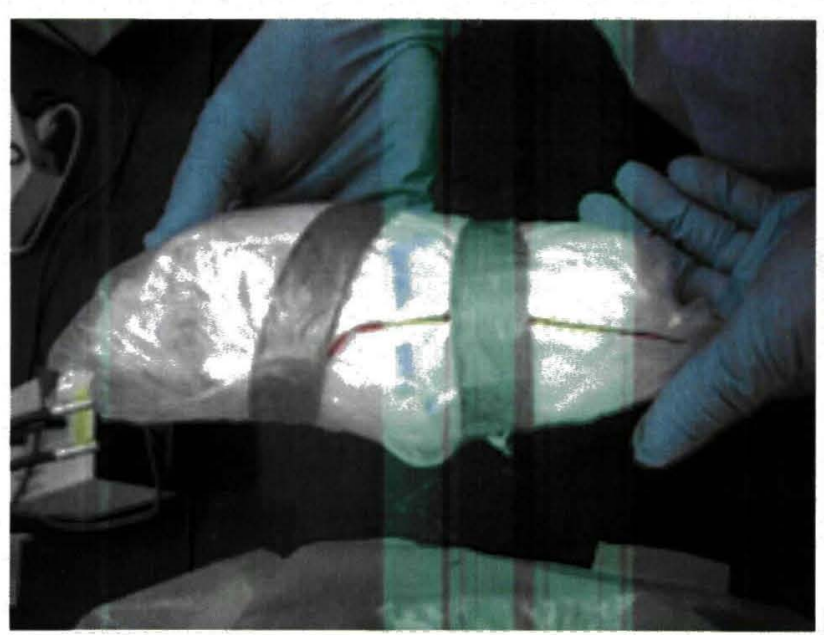

Photo 7. An Elbow
Volume F trash..

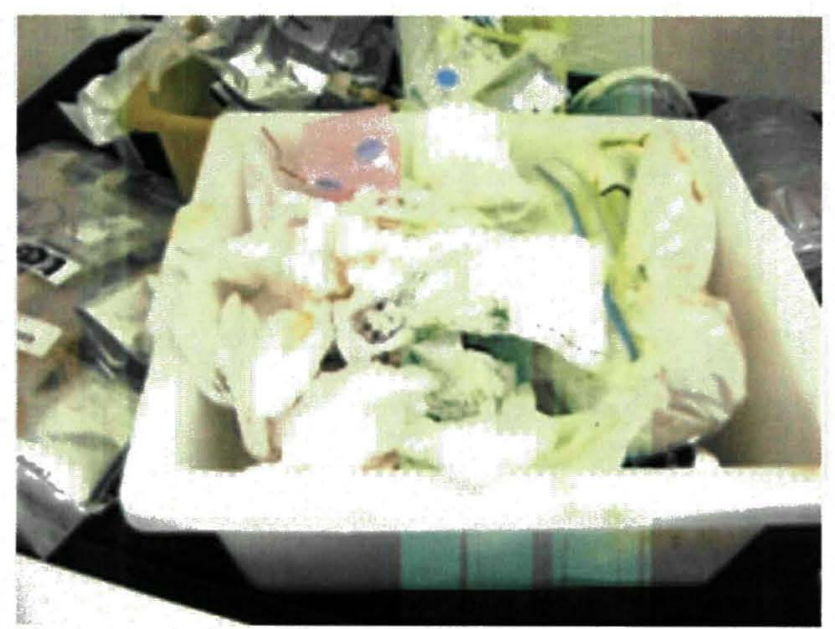

Photo 9. Office trash, e.g., paper, personal hygiene wastes, e.g., wipes, and other wate after separation and categorization. These items were from a food 'football in the Shuttle Volume F trash.

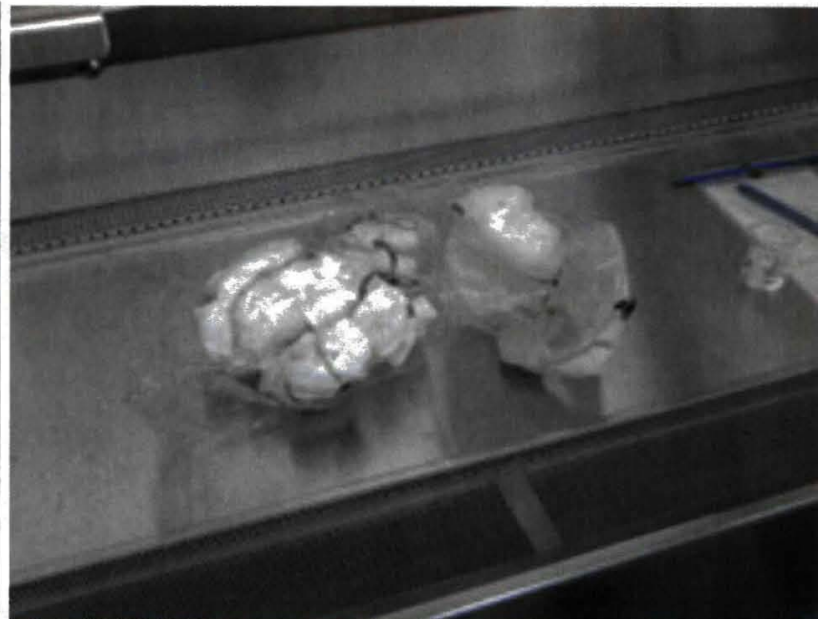

Photo 8. Contents of an Elbow pack'football in the Class 2 Biological Hazard Containment laminar flow hood for processing.

American Institute of Aeronautics and Astronautics 


\begin{tabular}{|c|c|c|c|c|c|c|c|}
\hline STS & Crew & Mission & Total trash & $\%$ & Weight of & Trash pro & tion 'rates' \\
\hline mission & size & duration & weight & water & water & Total wet wt. & Water in trash \\
\hline & & (days) & $\left(\mathrm{kg}_{\mathrm{wet}}\right)$ & $(\%)$ & $\left(\mathrm{kg}_{\text {water }}\right)$ & $\left(\mathrm{kg}_{\mathrm{wet}} \mathrm{CM}-\mathrm{d}^{-1}\right)$ & $\left(\mathrm{kg}_{\text {water }} \mathrm{CM}-\mathrm{d}^{-1}\right)$ \\
\hline 129 & 6 & 11 & 43.4 & 26.7 & 11.6 & 0.657 & 0.175 \\
\hline 130 & 6 & 14 & 58.3 & 36.2 & 17.2 & 0.693 & 0.204 \\
\hline 131 & 7 & 15 & 52.7 & 36.7 & 19.4 & 0.502 & 0.184 \\
\hline 132 & 6 & 12 & 40.0 & 35.5 & 9.4 & 0.556 & 0.131 \\
\hline \multicolumn{6}{|c|}{ Average, $n=4$} & 0.602 & 0.154 \\
\hline \multicolumn{6}{|c|}{ Standard deviation } & 0.089 & 0.030 \\
\hline
\end{tabular}

Determination of weight distribution and water content of STS trash by category.

Table 2 is a summary of the trash wet weight and water distribution by STS mission. Because mission duration and crew size should have an effect on the amount of trash generated, the last two columns on the right show the production 'rate', in mass per crew member per day. On this basis, STS 130 had the most trash as well as the most water in the trash. The average production rates for wet trash was $0.60 \mathrm{~kg} \mathrm{crew}^{-1} \mathrm{day}^{-1}$ and water in trash was 0.15 $\mathrm{kg} \mathrm{crew}^{-1}$ day $^{-1}$. Nearly one quarter of the shuttle trash was water. These data on trash water content should help in the deciding if whether water recovery from crew trash should be considered. If these data were used to estimate trash amounts for a longer duration mission, then, for instance, for a crew of 4 over a 180 day mission, e.g., on the lunar surface under some Constellation scenarios, the total amount of trash would be in the range of $430 \mathrm{~kg}$ of total wet waste and $110 \mathrm{~kg}(\sim 110$ liters) of water. Storage disposal of this trash would require a rather large volume. Unfortunately, we did not estimate the volume of the Volume $\mathrm{F}$ trash in this study.

The categories that were assigned to waste items during the inventory of trash contents were: (1) Personal Hygiene - which consisted of towels, cleaning supplies, used and unused MAGs, Elbow packs, and wipes; (2) Drink items - which consisted of drink pouches and containers of breakfast drinks, water, fruit drinks, etc.; (3) Food waste including packaging; (4) Office waste and supplies - paper, gloves, tissues; (5) Plastic film - the outer bags of Volume F bag, Bags A, B, and C, and the outer covering of 'footballs' which consisted of plastic bags and duct tape, and ziplock-style bags; and (6) Miscellaneous, which were silica gel packets for STS 129 only.

Table 3 gives a summary of the wet weight and water distribution by waste category. Personal hygiene wastes made up the largest category of waste at $43 \%$ of the total trash, and also had the highest water content, $69 \%$. In data not shown in this report, the MAGs and the elbow packs contributed the most to personal hygiene wastes in both wet weight and amount of water. Because of the high water absorption capacity of the MAG diaper material, it took nearly a month of drying at $70^{\circ} \mathrm{C}$ to reach a constant weight for the MAGs. If a short processing time for water recovery is important, then this waste may cause problems. The two other waste categories that contained water were the drink items and food items, at $16 \%$ and $19 \%$ of the total trash water and $14 \%$ and $19 \%$ of total waste.

\begin{tabular}{|l|c|c|c|c|}
\hline $\begin{array}{l}\text { Table 3. Weight and water distribution in STS trash by category. Sum of the four STS missions } \\
\text { in this study. }\end{array}$ & $\begin{array}{c}\text { Total wet } \\
\text { weight }(\mathrm{kg})\end{array}$ & $\begin{array}{c}\text { Percent of } \\
\text { total trash }\end{array}$ & $\begin{array}{c}\text { Total water } \\
\text { weight }(\mathrm{kg})\end{array}$ & $\begin{array}{c}\text { Percent of } \\
\text { total water }\end{array}$ \\
\hline Waste category & 84.2 & $43.3 \%$ & 39.5 & $68.7 \%$ \\
\hline Personal Hygiene & 26.9 & $13.9 \%$ & 9.2 & $16.1 \%$ \\
Drink items & 37.3 & $19.2 \%$ & 8.7 & $15.2 \%$ \\
Food, incl packaging & 2.7 & $1.4 \%$ & 0.0 & $0.0 \%$ \\
Office waste & 18.3 & $9.4 \%$ & 0.0 & $0.0 \%$ \\
Plastic film & 0.6 & $0.3 \%$ & 0.0 & $0.0 \%$ \\
Misc. & & & &
\end{tabular}


Table 4 ( $a, b, c$, and $d)$ shows the contents of individual bags of Shuttle trash that were received by KSC and included more than the Volume $\mathrm{F}$ trash compartment. Additional bags of trash were labeled by us, when we received them, as Bag A, Bag B, and Bag C so we could keep track of the waste source(s). The number of these bags for each mission were: one (Bag A) for STS 129 (Table 4a), three (Bag A, Bag B, and Bag C) for STS 130, two (Bag A, Bag B) for STS 131, and three (Bag A, Bag B, and Bag C) for STS 132.

\section{Discussion}

The Advanced Life Support (ALS) Baseline Values and Assumptions Document ${ }^{2}$ (BVAD) provides a good summary and analysis of 'Historical Waste Loads from Space Transportation System Missions' from a number of other documents and manuscripts (Golub and Wydeven ${ }^{3}$, Garcia ${ }^{4}$, Ground ${ }^{5}$, and Maxwell [data published in a Boeing Internal Document]) prior to it's publication date in 2004. According to this report the Volume F wet trash had been characterized for six shuttle missions, but only one of these had visited the ISS. These data were used in the BVAD to provide data for development of a waste model to support the Waste Subsystem analysis within the ALS project. The average amount of trash generated during these missions was $1.39 \mathrm{~kg} \mathrm{CM- \textrm {d } ^ { - 1 }}$ versus the present

Table 4a. Weight and moisture distribution of categories of waste in STS 129 trash.

\begin{tabular}{|c|c|c|c|c|}
\hline Source & Waste Category & Wet weight (g) & $\%$ moisture & Calculated Water (g) \\
\hline \multirow[t]{7}{*}{ Bag "A" } & Personal Hygiene & 2,673 & $15.5 \%$ & 414 \\
\hline & Drink items & 3,240 & $25.0 \%$ & 810 \\
\hline & Food, including packaging & 700 & $4.4 \%$ & 31 \\
\hline & Office waste & 184 & $0.0 \%$ & - \\
\hline & Plastic film & 2,080 & $0.0 \%$ & - \\
\hline & Misc. & 590 & $0.0 \%$ & - \\
\hline & Subtotal & 9,467 & & 1,255 \\
\hline \multirow[t]{7}{*}{ Volume $\mathrm{F}$} & Personal Hygiene & 18,912 & $27.2 \%$ & 5,136 \\
\hline & Drink items & 2,020 & $45.8 \%$ & 2,020 \\
\hline & Food, including packaging & 8,902 & $35.5 \%$ & 3,164 \\
\hline & Office waste & 67 & $0.0 \%$ & - \\
\hline & Plastic film & 4,000 & $0.0 \%$ & - \\
\hline & Subtotal & 33,902 & & 10,321 \\
\hline & Grand total & 43,368 & $26.7 \%$ & 11,576 \\
\hline
\end{tabular}

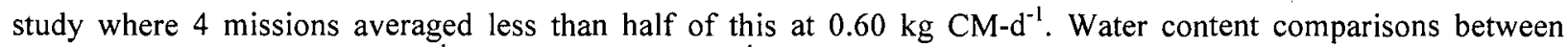

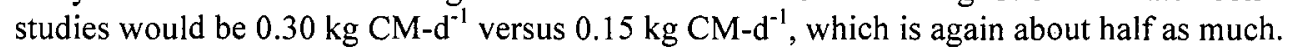

The most detailed of the studies cited in the BVAD was the one by Golub and Wydeven ${ }^{3}$ for STS 51D which found $49 \mathrm{~kg}$ of total waste, of which $28 \mathrm{~kg}$ was food-related trash. Food plastic packaging and other plastics and paper amounted to almost $47 \%$ of the total trash. Total water content of the trash was only $9.6 \%$. This is the lowest reported amount of water for the Volume F trsh in the six STS missions mentioned in the BVAD and the 4 STS missions in the present report.

This report publishes detailed results for waste categories of the Volume F trash and other wastes for STS missions. As Table $4 \mathrm{a}, \mathrm{b}, \mathrm{c}$, and $\mathrm{d}$ shows, the contents of trash bags varied between missions, but some trends were noted. Most of the drink pouches were in Bags A, B, and C, $62 \%$ for STS $129,93 \%$ for STS $30,82 \%$ for STS 131 , and $88 \%$ for STS 132 when compared with Volume F. Most of the food items were in the Volume F trash - $93 \%$ for STS $129,62 \%$ for STS $130,91 \%$ for STS 131 , and $96 \%$ for STS 132 . Wastes in the personal hygiene category were mostly found in the Volume F trash for STS 129, 131, and $132-88 \%, 97 \%$ and $80 \%$-- but for STS 130 most of the personal hygiene wastes were in Bags $\mathrm{A}, \mathrm{B}$, and $\mathrm{C}$. The reason for this waste distribution is not known to us, but it could be that Volume $F$ trash was collected on orbit and the other trash bags - A, B, and C - contained material in transit, i.e., between Earth and orbit. These data also show the importance of dividing wastes into categories before 


\begin{tabular}{|c|c|c|c|c|}
\hline Source & Waste Category & Wet weight $(\mathrm{g})$ & $\%$ moisture & Calculated Water (g) \\
\hline Bag A & $\begin{array}{r}\text { Personal Hygiene } \\
\text { Drink items } \\
\text { Food, incl packaging } \\
\text { Office waste } \\
\text { Plastic film } \\
\text { Subtotal }\end{array}$ & $\begin{array}{c}9,888 \\
3,148 \\
928 \\
100 \\
\\
\mathbf{1 4 , 0 6 4}\end{array}$ & $\begin{array}{c}43.8 \% \\
25.4 \% \\
6.0 \%\end{array}$ & $\begin{array}{c}4,332 \\
799 \\
56\end{array}$ \\
\hline Bag B & $\begin{array}{r}\text { Personal Hygiene } \\
\text { Drink items } \\
\text { Food, incl packaging } \\
\text { Office waste } \\
\text { Plastic film } \\
\text { Subtotal }\end{array}$ & $\begin{array}{c}4,354 \\
3,239 \\
1,181 \\
40 \\
\mathbf{8 , 8 1 4}\end{array}$ & $\begin{array}{l}28.1 \% \\
28.4 \% \\
16.8 \%\end{array}$ & $\begin{array}{c}1,221 \\
921 \\
199 \\
\\
2,341\end{array}$ \\
\hline Bag C & $\begin{array}{r}\text { Personal Hygiene } \\
\text { Drink items } \\
\text { Food, incl packaging } \\
\text { Office waste } \\
\text { Plastic film } \\
\text { Subtotal }\end{array}$ & $\begin{array}{c}3,838 \\
798 \\
1,642 \\
- \\
\\
6,278\end{array}$ & $\begin{array}{c}43.8 \% \\
18.8 \% \\
6.1 \%\end{array}$ & $\begin{array}{l}1,681 \\
150 \\
101 \\
\\
1,932\end{array}$ \\
\hline \\
\hline \multirow[t]{2}{*}{ Volume F } & $\begin{array}{r}\text { Personal Hygiene } \\
\text { Drink items } \\
\text { Food, incl packaging } \\
\text { Office waste } \\
\text { Plastic film } \\
\text { Shipped to ARC }\end{array}$ & $\begin{array}{c}10,230 \\
557 \\
6,170 \\
- \\
1,240 \\
10,900 \\
\end{array}$ & $\begin{array}{l}60.8 \% \\
54.8 \% \\
18.8 \%\end{array}$ & $\begin{array}{c}6224 \\
305 \\
1,163\end{array}$ \\
\hline & Subtotal & 29,097 & & 7,692 \\
\hline . & Grand total & 58,253 & $36.2 \%$ & 1,7152 \\
\hline
\end{tabular}

taking samples for microbial characterization or for further treatment for water recovery and/or waste sanitization or sterilization.

Of note is that approximately $30 \%$ of the Volume F wastes from STS 130 (Table $4 \mathrm{~b}$ ) and $34 \%$ of wastes from Bags A, B, C and the Volume F trash from STS 132 were sent to WMS scientists and engineers at ARC for their use as feed material for solid waste processing technologies under development there, such as the Heat Melt Compactor $^{6}$. These wastes will complement their studies which have been conducted to date with model or simulated space mission wet trash. 


\begin{tabular}{|c|c|c|c|c|}
\hline Source & Waste Category & Wet weight $(\mathrm{g})$ & $\%$ moisture & Calculated Water $(\mathrm{g})$ \\
\hline \multirow{6}{*}{ Bag A } & Personal Hygiene & 400 & $12.3 \%$ & 49 \\
\hline & Drink items & 3,140 & $25.6 \%$ & 803 \\
\hline & Food, incl packaging & 460 & $3.9 \%$ & 18 \\
\hline & Office waste & 640 & & \\
\hline & Plastic film & 2,720 & & \\
\hline & Subtotal & 7,360 & & 5,187 \\
\hline \multirow{6}{*}{ Bag B } & Personal Hygiene & 460 & $7.3 \%$ & 33 \\
\hline & Drink items & 3,480 & $28.3 \%$ & 984 \\
\hline & Food, incl packaging & 560 & $2.3 \%$ & 13 \\
\hline & Office waste & 460 & & \\
\hline & Plastic film & 1,200 & & \\
\hline & Subtotal & 6,160 & & 1,031 \\
\hline \multirow{7}{*}{ Volume F } & Personal Hygiene & 24,680 & $61.6 \%$ & 15,193 \\
\hline & Drink items & 1,460 & $24.8 \%$ & 361 \\
\hline & Food, incl packaging & 10,761 & $17.7 \%$ & 1,909 \\
\hline & Office waste & - & & \\
\hline & Plastic film & 2,300 & & \\
\hline & Subtotal & 39,201 & & 17,463 \\
\hline & Grand total & 52,721 & $45 \%$ & 23,680 \\
\hline
\end{tabular}

\section{Conclusion}

The composition of trash returned from four recent STS missions was determined. The trash material was 'Volume F' trash and other trash, in large zip-lock bags, that accompanied the Volume $F$ trash. This report covers trash content, weight and water content. A companion report will present data on the microbial characterization of this trash. STS trash was usually made available within 2 days of landing at KSC. The Volume F bag was weighed, opened and the contents were catalogued and placed into one of the following categories: food waste (and containers), drink containers, personal hygiene items - including EVA maximum absorbent garments (MAGs) and Elbow packs (daily toilet wipes, etc), paper, and packaging materials - plastic film and duct tape. Trash generation rates for the four STS missions: Total wet trash was $0.602 \pm 0.089 \mathrm{~kg}_{\text {wet }}$ crew $^{-1} \mathrm{~d}^{-1}$ containing about $25 \%$ water at $0.154 \pm 0.030 \mathrm{~kg}_{\text {water }} \mathrm{crew}^{-1} \mathrm{~d}^{-1}$ (avg \pm stdev). Cataloguing by category: personal hygiene wastes accounted for $50 \%$ of the total trash and $69 \%$ of the total water for the four missions; drink items were $16 \%$ of total weight and $16 \%$ water; food wastes were $22 \%$ of total weight and $15 \%$ of the water; office waste and plastic film were $2 \%$ and $11 \%$ of the total waste and did not contain any water. The results can be used by NASA to determine requirements and criteria for Waste Management Systems on future missions. 
Table 4d. Weight and moisture distribution of categories of waste in STS 132 trash.

\begin{tabular}{|c|c|c|c|c|}
\hline Source & Waste Category & Wet weight (g) & $\%$ moisture & Calculated Water $(\mathrm{g})$ \\
\hline \multirow{7}{*}{ Bag A } & Personal Hygiene & 940 & $33.5 \%$ & 315 \\
\hline & Drink items & 2,260 & $31.6 \%$ & 714 \\
\hline & Food, incl packaging & 120 & $8.2 \%$ & 10 \\
\hline & Office waste & 100 & & \\
\hline & Plastic film & 600 & & \\
\hline & Shipped to ARC & 1,600 & & \\
\hline & Subtotal & 5,620 & $25.8 \%$ & 1,038 \\
\hline \multirow{7}{*}{ Bag B } & Personal Hygiene & 740 & $29.8 \%$ & 221 \\
\hline & Drink items & 1,680 & $36.4 \%$ & 612 \\
\hline & Food, incl packaging & 60 & $51.8 \%$ & 31 \\
\hline & Office waste & 340 & & \\
\hline & Plastic film & 560 & & \\
\hline & Shipped to ARC & 1,545 & & \\
\hline & Subtotal & 4,925 & $25.6 \%$ & 864 \\
\hline & $i^{\prime}$ & & & \\
\hline \multirow{7}{*}{ Bag C } & Personal Hygiene & 40 & & - \\
\hline & Drink items & 1,180 & $43.9 \%$ & 517 \\
\hline & Food, incl packaging & 60 & & - \\
\hline & Office waste & 720 & & \\
\hline & Plastic film & 2,000 & & \\
\hline & Shipped to ARC & 2,182 & & \\
\hline & Subtotal & 6,182 & $12.9 \%$ & 517 \\
\hline \multirow{8}{*}{ Volume F } & Personal Hygiene & 7,080 & $66.7 \%$ & 4,720 \\
\hline & Drink items & 720 & $33.9 \%$ & 244 \\
\hline & Food, incl packaging & 5,738 & $35.8 \%$ & 2,055 \\
\hline & Office waste & 20 & & \\
\hline & Plastic film & 1,620 & & \\
\hline & Shipped to ARC & 8,136 & & \\
\hline & Subtotal & 23,314 & $46.2 \%$ & 7,020 \\
\hline & Grand total & 40,042 & $23.6 \%$ & 9,439 \\
\hline
\end{tabular}

\section{Acknowledgments}

The research reproted in this paper was supported by NASA Exploration Life Support (currently named Life Support and Habitation Systems) project through the Waste Management System element.

\section{References}

${ }^{1}$ Kish, A.. L., Hummerick, M. P., Roberts, M. S., Garland, J. L., Maxwell, S., Mills, A. "Biostability and Microbiological Analysis of Shuttle Crew Refuse," SAE Tech Rep. 2002-01-2356, 2002.

${ }^{2}$ Hanford, A. J., "Advanced Life Support Baseline Values and Assumptions Document," CTSD-ADV-484 A, National Aeronautics and Space Administration, Lyndon B. Johnson Space Center, Houston, Texas. 2004. 


\footnotetext{
${ }^{3}$ Wydeven, T., and Golub, M. A., (1991) "Waste Streams in a Crewed Space Habitat," Waste Management and Research Vol. 9, pp. 91-101, 1991.

${ }^{4}$ Garcia, R. "Space Transportation System 29 (STS-29) Trash Evaluation Final Report", JSC-SP-89-1, National Aeronautics and Space Administration, Lyndon B. Johnson Space Center, Houston, Texas. 1989.

${ }^{5}$ Grounds, P. "Space Transportation System 35 (STS-35) Trash Evaluation Final Report", JSC-SP-90-2, National Aeronautics and Space Administration, Lyndon B. Johnson Space Center, Houston, Texas. 1990.

${ }^{6}$ Pace, G.S., and Fisher, J., "Testing and Analysis of the First Plastic Melt Waste Compactor Prototype," SAE Tech Rep. 2005-01-3080, 2005.
} 


\section{Characterization of Volume $\mathrm{F}$ trash from four recent STS missions: weights, categorization, water content}

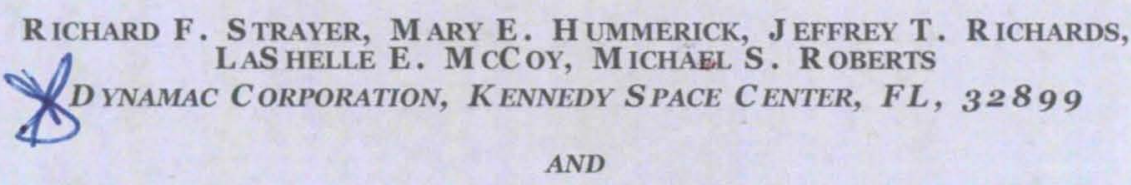

R AYMOND M. W HEELER

S URFACE S YSTEMS D IVISION, KENNEDY S PACE CENTER, FL, 32899

\section{Introduction}

- KSC project - Microbial Characterization of Solid Wastes

- Provide microbiological support of

o Waste Management Systems element at ARC

- NASA's Life Support and Habitation Systems program at JSC

- WMS role

Q Develop technologies and approaches to manage numerous types of solid wastes materials generated in future, long duration human space missions

o Protect crew health \& well being, optimize waste storage volume, minimize crew handling, recover resources, meet planetary protection guidelines 


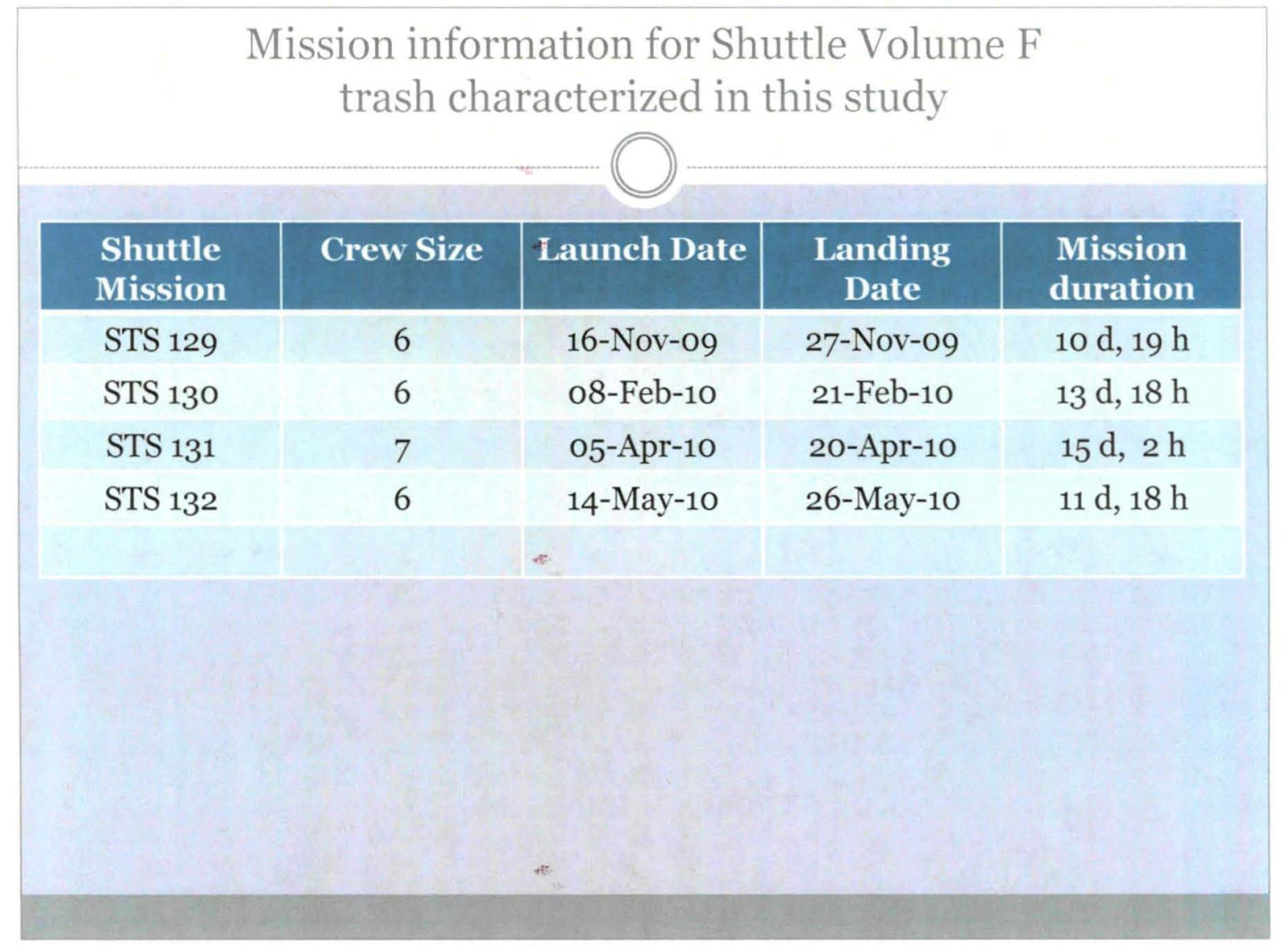

\section{Sequence of events after each landing}

- Pick up Volume F compartment wet trash from landing support personnel, usually within $48 \mathrm{hrs}$ of landing

- Store trash at room temperature

- 1 - 3 days until processed and characterized.

\section{- Process and characterize trash}

o Determine wet weights

o Open exterior bags and catalog contents. Photograph.

- Trash bundles ('footballs') aseptically opened and contents sorted, cataloged, and weighed, by category

- Subsamples from each category were taken for dry weight determination and microbiological analyses. 


\section{Trash categorization flow chart}
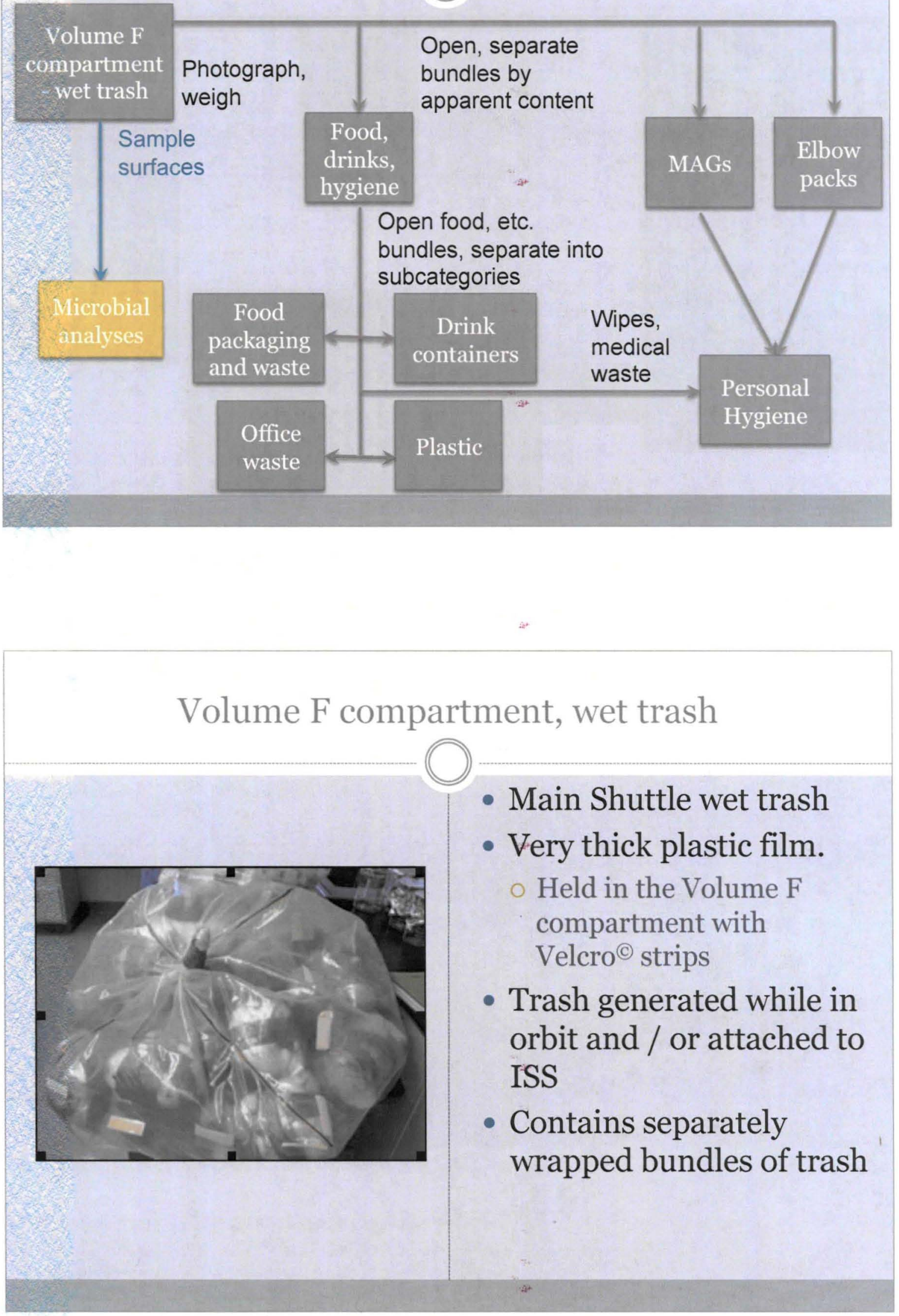


\section{Other bags of trash}

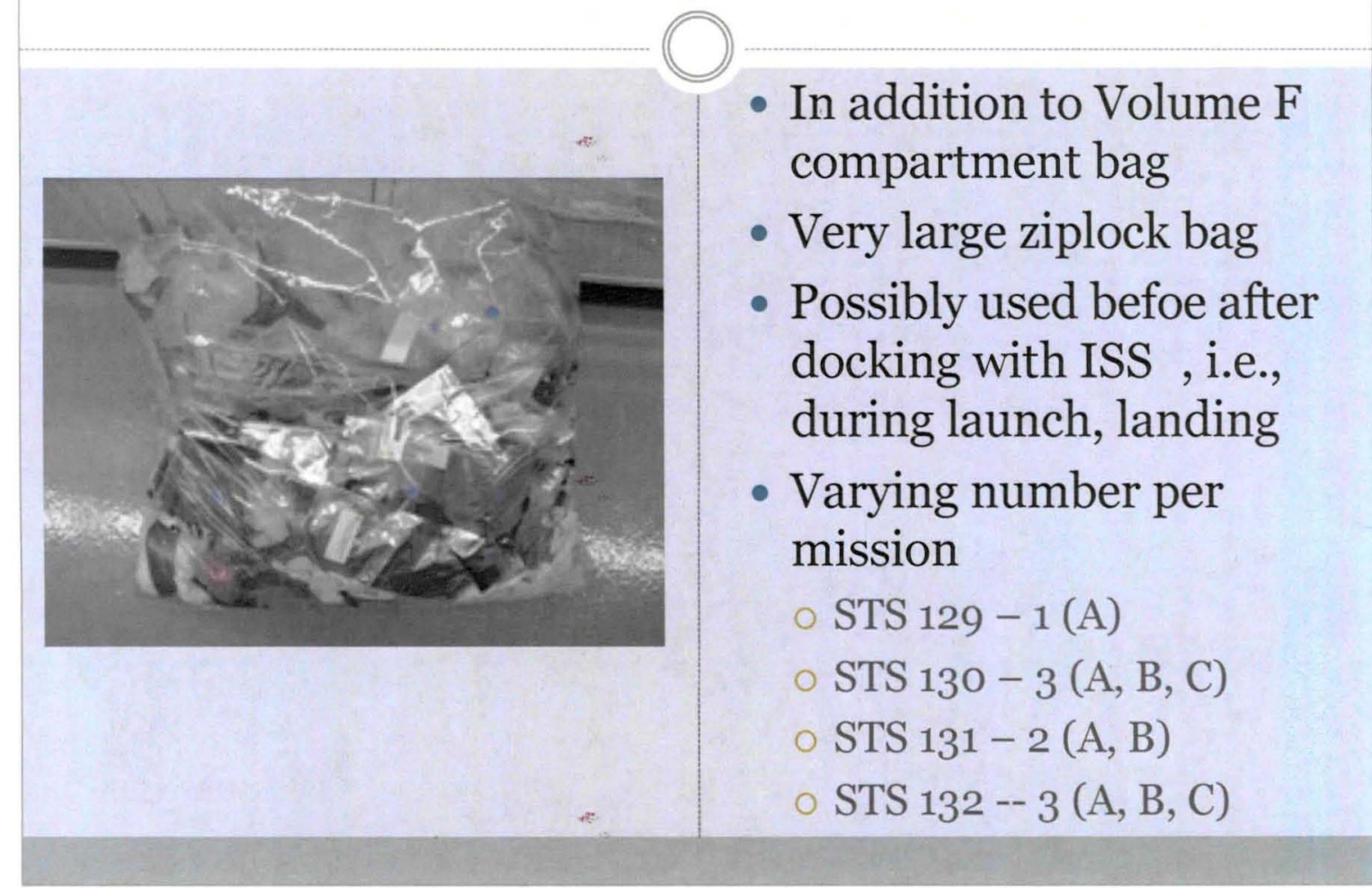

Trash bundles ('footballš') in Volume F compartment trash

Mixture of different types of trash bundles

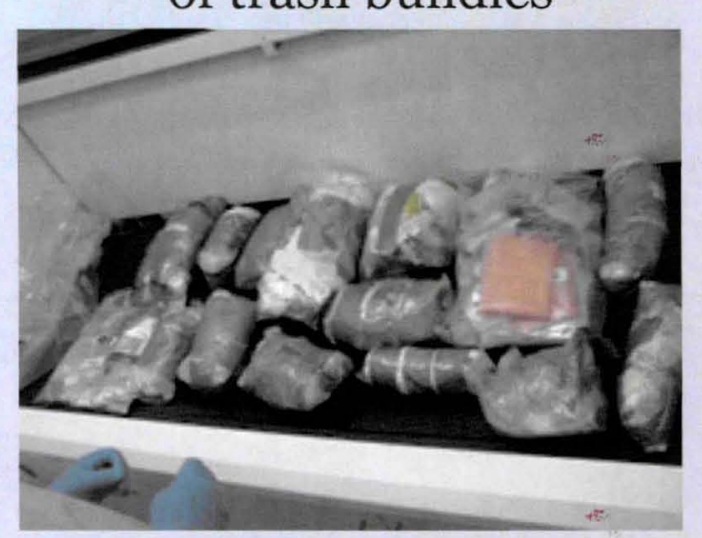

- Smaller plastic bags or liners

- Closed by wrapping with silver duct tape

- By contents, first cut placement into categories

- Food packaging and food, drink containers, personal hygiene, office

- MAGs

- Elbow packs/toilet wipes 


\section{Food, drinks, wipes, etc. in a trash bundle}

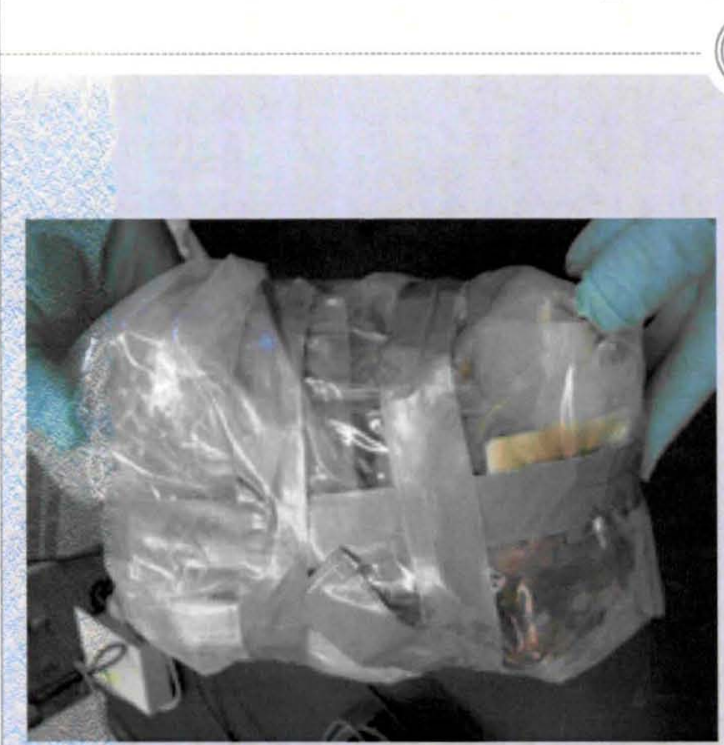

- Heterogeneous mixture of trash, which required cutting the bundles open to remove trash and place it into categories

EVA MAGs, toilet wipes, etc in 'Elbow' pack

Maximum Absorbancy

Garment (MAG)

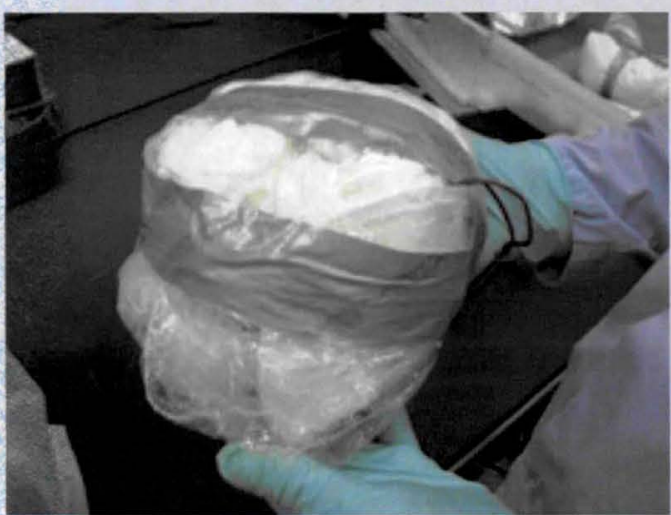

0

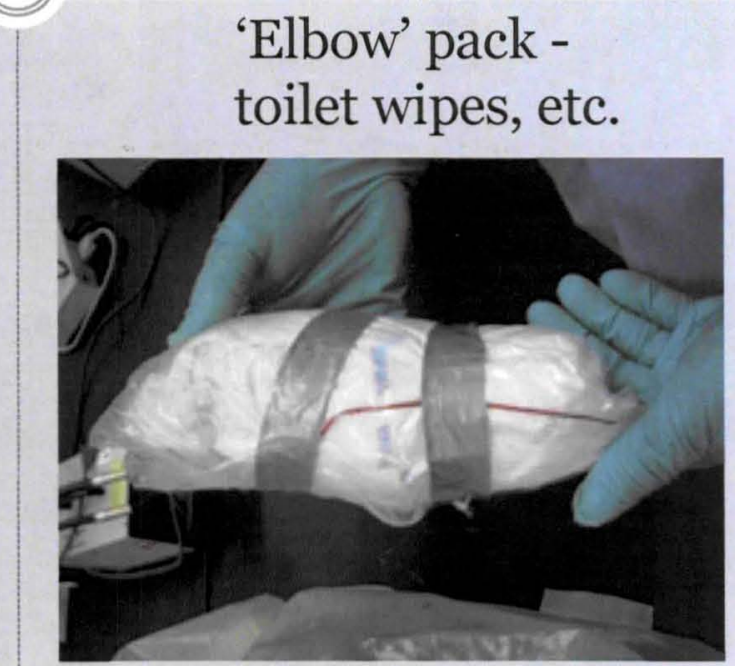




\section{Separation of bundle contents into categories}

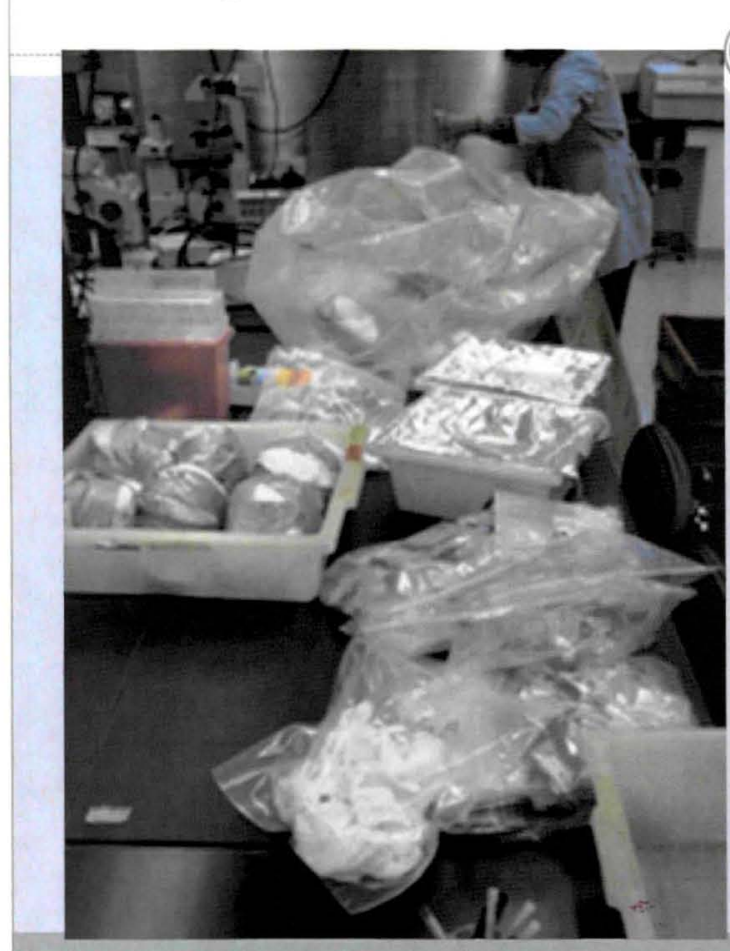

$\leftarrow$ Project personnel categorizing and cataloging trash bundles

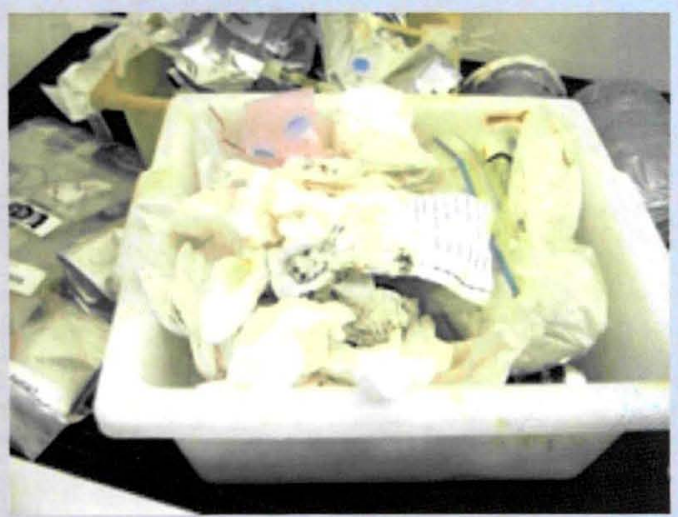

$\uparrow$ Office trash, etc. after separation

\section{Weight distribution by STS mission}

\begin{tabular}{c|c|c|c|c|c|}
$\begin{array}{c}\text { STS } \\
\text { mission }\end{array}$ & $\begin{array}{c}\text { Crew } \\
\text { Size }\end{array}$ & $\begin{array}{c}\text { Mission } \\
\text { Duration } \\
\text { (days) }\end{array}$ & $\begin{array}{c}\text { Wet } \\
\text { weight } \\
\left(\mathrm{kg}_{\text {wet }}\right)\end{array}$ & $\begin{array}{c}\text { Water } \\
\text { content } \\
(\%)\end{array}$ & $\begin{array}{c}\text { Calc. water } \\
\text { weight } \\
\left(\mathrm{kg}_{\text {water }}\right)\end{array}$ \\
\hline
\end{tabular}

$129 \quad 6$

$130 \quad 6$

11

43.4

24.2

10.5

$131 \quad 7$

14

58.3

36.2

17.2

132

15

52.7

36.7

19.4

40.0

$35 \cdot 5$

9.4

- STS 130 had the most trash and the most water in the trash

- Nearly $25 \%$ of the trash was water. 


\section{Trash production rates}

\begin{tabular}{|c|c|c|c|c|}
\hline STS Mission & Crew Size & $\begin{array}{c}\text { Mission } \\
\text { Duration }\end{array}$ & Total wet wt. & $\begin{array}{c}\text { Water in } \\
\text { trash }\end{array}$ \\
\hline 129 & 6 & $($ days $)$ & $\left(\mathrm{kg}_{\text {wet }} \mathrm{CM}-\mathrm{d}^{-1}\right)$ & $\left(\mathrm{kg}_{\text {water }} \mathrm{CM}-\mathrm{d}^{-1}\right)$ \\
130 & 6 & 11 & 0.657 & 0.159 \\
131 & 7 & 14 & 0.693 & 0.204 \\
132 & 6 & 15 & 0.502 & 0.184 \\
& & Average, $\mathrm{n}=4$ & 0.566 & 0.131 \\
& & Std. dev. & 0.602 & 0.170 \\
\hline
\end{tabular}

CM-d is crew member day

\section{Extrapolations from these data for longer duration missions}

- Estimating trash amounts for longer duration missions from these short duration missions

- E.g., for Constellation scenario on the lunar surface

o Crew size: 4

o Mission duration: 180 days

o Estimated total trash: $430 \mathrm{~kg}$

o Estimated water amount: $110 \mathrm{~kg}(\sim 110 \mathrm{~L})$

- Disposal by storage would require a rather large volume.

- Should water recovery from trash be considered? 


\begin{tabular}{|c|c|c|c|c|}
\hline Waste category & $\begin{array}{c}\text { Total wet } \\
\text { weight (kg) }\end{array}$ & $\begin{array}{l}\text { Percent of } \\
\text { total trash }\end{array}$ & $\begin{array}{l}\text { Weight of } \\
\text { water }(\mathrm{kg})\end{array}$ & $\begin{array}{l}\text { Percent of } \\
\text { total water }\end{array}$ \\
\hline Personal hygiene $^{1}$ & 84.2 & $50 \%$ & 39.5 & $69 \%$ \\
\hline Drink items ${ }^{2}$ & 26.9 & $16 \%$ & 9.2 & $16 \%$ \\
\hline Food, packaging & $37 \cdot 3$ & $22 \%$ & 8.7 & $15 \%$ \\
\hline Office waste ${ }^{3}$ & $2.7=$ & $2 \%$ & 0.0 & o\% \\
\hline Plastic 4 & $18.3^{t-}$ & $11 \%$ & 0.0 & o \% \\
\hline Misc. 5 & 0.6 & $0.3 \%$ & 0.0 & $0 \%$ \\
\hline Shipped to ARC & $(24.4)$ & -- & ND & ND \\
\hline \multicolumn{5}{|c|}{$\begin{array}{l}1 \text { - towels, cleaning supplies, used \& unused MAGs, Elbow packs, wipes } \\
2 \text { - drink pouches \& containers - breakfast drinks, water, fruit drinks } \\
3 \text { - paper, gloves, tissues } \\
4 \text { - plastic film, outer bags of Volume F, bags A, B, and/or C, outer plastic covering of bundles, duct tape } \\
5 \text { - silica get packs for STS } 129 \text { only }\end{array}$} \\
\hline
\end{tabular}

\section{Water and weight distribution by trash category}

- Personal hygiene waste - largest by weight and water content

- Mostly due to MAGs and Elbow packs

- MAGs could take nearly a month to get a dry weight (at $70^{\circ} \mathrm{C}$ )

- If a short processing time for water recovery is important, this waste may cause problems

- Drink wastes and food packaging were the other trash categories that contained water 


\section{Category variability between the 4 STS missions}

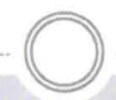

- In the paper Appendix, more detailed results. Trends noted:

o Most of the drink pouches were in bags A, B, and C rather than in the Volume F bag

Most of the food items were in the Volume F bag

Q Most of the personal hygiene items were in the Volume $\mathrm{F}$ bag except for STS 130 (bags A, B, and C)

- The data shown in the Appendix show the importance of dividing waste into categories before

Taking samples for microbial characterization

o Further treatment for water recovery

\section{Conclusions}

- The composition of wet trash returned from 4 recent STS missions was determined within 3 to 5 days of landing

0 Trash content, weight, and water content

o Waste generation rates: $0.60 \mathrm{~kg} \mathrm{crew}^{-1} \mathrm{~d}^{-1}, 0.17 \mathrm{~kg} \mathrm{crew}^{-1} \mathrm{~d}^{-1}$ water.

- Trash contents were placed into categories

o Personal hygiene - Total: $50 \%$ total, Water: $69 \%$

o Drinks - Total: $16 \%$, Water: $16 \%$.

o Food related - Total: $22 \%$, Water: $15 \%$

o Other waste - Total: $2 \%$ Office, $11 \%$ Plastic Water: none 


\section{Conclusions (cont.)}

- NASA can use these results to determine requirements and criteria for Waste Management Systems, i.e., treatment technologies, on future missions

\section{Acknowledgments}

- This research was supported by NASA Life Support and Habitation Systems (ne: Exploration Life Suport) project (JSC) through the Waste Management Systems element (ARC) 


\title{
Characterization of Volume $\mathrm{F}$ trash from four recent STS missions: weights, categorization, water content
}

\author{
Richard F. Strayer, ${ }^{1}$ Mary E. Hummerick, ${ }^{2}$ Jeffrey T. Richards, ${ }^{3}$ LaShelle E. McCoy, ${ }^{4}$ Michael S. Roberts ${ }^{5}$ \\ Dynamac Corporation, Kennedy Space Center, FL, 32899 \\ and \\ Raymond M. Wheeler ${ }^{6}$ \\ Surface Systems Division, Kennedy Space Center, FL, 32899
}

\begin{abstract}
The fate of space-generated solid wastes, including trash, for future missions is under consideration by NASA. Several potential treatment options are under consideration and active technology development. Potential fates for space-generated solid wastes are: Storage without treatment; storage after treatment(s) including volume reduction, water recovery, sterilization, and recovery plus recycling of waste materials. Recyling might be important for partial or full closure scenarios because of the prohibitive costs associated with resupply of consumable materials. For this study, we determined the composition of trash returned from four recent STS missions. The trash material was 'Volume F' trash and other trash, in large zip-lock bags, that accompanied the Volume $\mathrm{F}$ trash. This is the first of two submitted papers on these wastes. This one will cover trash content, weight and water content. The other will report on the microbial characterization of this trash. STS trash was usually made available within 2 days of landing at KSC. The Volume F bag was weighed, opened and the contents were cataloged and placed into one of the following categories: food waste (and containers), drink containers, personal hygiene items - including EVA maximum absorbent garments (MAGs)and Elbow packs (daily toilet wipes, etc), paper, and packaging materials - plastic film and duct tape. Trash generation rates for the four STS missions: Total wet trash was $0.602 \pm 0.089 \mathrm{~kg}_{\text {wet }}$ crew $^{-1} \mathrm{~d}^{-1}$ containing about $25 \%$ water at $0.154 \pm$ $0.030 \mathrm{~kg}_{\text {water }} \mathrm{crew}^{-1} \mathrm{~d}^{-1}$ (avg \pm stdev). Cataloging by category: personal hygiene wastes accounted for $50 \%$ of the total trash and $69 \%$ of the total water for the four missions; drink items were $16 \%$ of total weight and $16 \%$ water; food wastes were $22 \%$ of total weight and $15 \%$ of the water; office waste and plastic film were $2 \%$ and $11 \%$ of the total waste and did not contain any water. The results can be used by NASA to determine requirements and criteria for Waste Management Systems on future missions.
\end{abstract}

\section{Nomenclature}

STS = U.S. Space Transport System, i.e., the shuttle.

KSC $=$ Kennedy Space Center, FL, USA.

EVA = Extra Vehicular Activity, i.e., space walks while in orbit

WMS $=$ Waste Management Systems element

\footnotetext{
${ }^{1}$ Research Scientist Sustainable Systems Research, Mail Code ESC-53, Kennedy Space Center, FL 32899.

${ }^{2}$ Research Scientist Sustainable Systems Research, Mail Code ESC-53, Kennedy Space Center, FL 32899.

${ }^{3}$ Research Scientist Sustainable Systems Research, Mail Code ESC-53, Kennedy Space Center, FL 32899.

${ }^{4}$ Research Scientist Sustainable Systems Research, Mail Code ESC-53, Kennedy Space Center, FL 32899.

${ }^{5}$ Research Scientist Sustainable Systems Research, Mail Code ESC-53, Kennedy Space Center, FL 32899.

${ }^{6}$ Senior Scientist, Surface Systems Division, Mail Code NE-S, Kennedy Space Center, FL 32899.
} 


\section{Introduction}

$\mathrm{T}$ HE Waste Management Systems (WMS) element of the Life Support and Habitation Systems program is responsible for the development of technologies and approaches to manage the numerous types of solid waste materials generated in future human space flight. Currently, STS and ISS utilize simple waste management methods, where trash is stored, and either burned during Earth reentry (Russian Progress vehicles) or returned to Earth (STS). Future long-duration missions will require more sophisticated methods for in-situ processing, storage and disposal of wastes. The WMS element is therefore engaged in designing, developing and testing technologies that: ensure the protection of the health and well-being of the crew; optimize waste storage volume; minimize crew handling; recover resources; and meet planetary protection guidelines.

WMS has a number of solid waste treatment technologies that are, or have been, under development. The goals of these treatments are to (1) reduce the volume of the waste because storage space is very limited on space vehicles, (2) remove and recover water because many wastes contain water and easily biodegraded organic compounds from food wastes and crew feces, (3) stabilize and make wastes safe for the crew and harmless to the environment, (4) contain waste to isolate it from the crew and the rest of the world, and dispose of the contained waste, and (5) process the waste for reuse of resources within the stored waste. Because a major reason behind goals (2), (3), and (4) are to eliminate hazards to crew caused by the presence of pathogenic or otherwise deleterious microorganisms in solid wastes, our efforts at KSC have been to provide support to WMS process technologies that have been designed to eliminate microbiological hazards. These technologies have been selected because they either remove and recover water, which microbes need to survive and grow, or they sterilize the solid waste, usually though heat.

The role of our support projects at KSC have been to characterize the microflora present in space-generated solid wastes such as food wastes, crew fecal wastes, and other wet organic wastes. These wastes typically contain easily biodegraded organic compounds that support microbial growth and proliferation. If solid wastes remain untreated or unprocessed and are then placed into storage, over time the labile organic components in the waste will likely be responsible for both microbial proliferation and microbial byproduct production of noxious odors.

Two studies at KSC in FY07 and FY08, respectively, have examined the microbial characterization of food wastes in simulated space mission trash, i.e., for a Lunar Base. However, the wastes were inoculated with saliva collected from volunteer donors after a vigorous mouth scrubbing with sterile swabs. Volunteer body wipes, in lieu of a shower, disinfectant and wet wipes of facility urinals and commodes, and dry wipes of laboratory tabletop surfaces were also added to the simulated waste after placing the wipes into a ziplock bags, which were then sealed. At the time, we felt that these inocula would 'simulate' what the wastes were inoculated with in a space habitat. However, the results of the study indicated that few human pathogens were present in the wastes, thus we wondered if the inocula might not be very representative. During these studies, we had access to the wet waste from the Volume F trash returned on each STS mission, but resources were not available to process these wastes for our microbiological studies. This all changed this past year as both access and resources could be used.

Although our primary goal was microbial characterization of the STS Volume F trash, we also had the opportunity to characterize, or survey, the contents of the trash in relation to total wet weights, water content, plastic film content, and to photodocument the trash contents. This paper reports our findings on this physical characterization of the Volume $\mathrm{F}$ trash from four recent shuttle missions. A second paper for this conference reports our results of the microbiological characterization of this trash (reference ).

\section{Materials and Methods}

\section{A. Approach}

Volume F wet trash and other large ziplock plastic bags, which also contained trash items, are generated on each STS mission, whether to the International Space Station (ISS) or not. As noted by Kish, et al. ${ }^{1}$, wet trash waste storage aboard the orbiter is in the Shuttle middeck area and is called the Volume F compartment. The wet trash and includes mealtime wastes such as leftover food and drink and the associated food packaging, personal hygiene articles, toilet wipes (termed "elbow packs" because of their shape), and Maximum Absorbancy Garment (MAG) worn by the crew during launch and extravehicular activities (EVA). The Volume F trash from four recent STS missions were available for this report and mission specifics are shown in Table 1.

\section{B. Sequence of sampling events for each shuttle landing at KSC}

Upon notification by shuttle personnel, usually within 48 hours of landing, the Volume F trash waste was picked up from landing support personnel. Trash was stored at room temperature, between 1 and 3 days, before it could be 


\begin{tabular}{|c|c|c|c|c|}
\hline Shttle Mission & Crew Size, & Launch Date & Landing Date & Mission duration \\
\hline STS 129 & 6 & 16-Nov-09 & 27-Nov-09 & 10 days, 19 hours, 16 minutes, 13 seconds \\
\hline STS 130 & 6 & $08-F e b-10$ & 21-Feb-10 & 13 days, 18 hours, 6 minutes, 24 seconds \\
\hline STS 131 & 7 & 05-Apr-10 & 20-Apr-10 & 15 days, 2 hours, 47 minutes, 10 seconds \\
\hline STS 132 & 6 & 14-May-10 & 26-May-10 & 11 days, 18 hours, 29 minutes, 9 seconds \\
\hline
\end{tabular}

processed and characterized. Processing and characterization, including microbial characterization from sample acquisition to dilutions to inoculation of enumeration media, usually took 2 to 3 work days.

First, total wet weight was determined of the entire Volume F trash and any accompanying large zip-lock bags of trash. The Volume $\mathrm{F}$ trash bag and accompanying bags were next opened and the contents were cataloged and photographed. The contents were smaller plastic liner bags, termed 'footballs' by former STS crews, that had been closed by wrapping them with duct tape. Footballs that contained what looked like food trash, drink pouches, or personal hygiene items were aseptically cut open and the contents were sorted and placed into categories. Footballs that obviously contained MAGs or elbow packs, i.e., toilet wipes, were not opened at this time, but placed into these categories. Next, the total wet weight of each category was determined and subsamples were taken, aseptically for microbiological analyses and some for dry weight determinations $\left(70{ }^{\circ} \mathrm{C}\right.$ until dry, usually overnight). During the physical categorization and opening of footballs, outer plastic bags and duct tape were placed into the plastic and packaging category to determine a total weight of this category.

\section{Results and Discussion}

\section{A. Separation, cataloging, and sampling of STS wet trash.}

Photos 1 through 8 show some of the representative pictures taken during the process of opening the trash bags and cataloging and categorizing the trash items. The main trash bag, the Volume F trash is shown in Photo 1. This bag was made of a very thick film plastic that appears to contain all trash generated while the shuttle was in orbit and while attached to the ISS. As can be seen through the semi-trasparent plastic, the Volume $\mathrm{F}$ trash contains individual 'footballs' of the various trash items. The term apparently comes from early STS crews which thought the shapes of these resembles the shape of American footballs. Each football contained items that had been placed in smaller plastic bags, or liners, that had been closed by wrapping with silver duct tape. After the outer Volume F bag was opened, the contents were cataloged and placed into categories that were defined as the cataloging process proceeded (Photo 3, Photo 4). In addition to the thick plastic film Volume F bag, there were separate, large ziplock plastic bags (Photo 2). These were not labeled so we called them Bag A, Bag B, or Bag C. Different shuttle missions had different numbers of these additional trash-containing bags. For STS 129 there was one of these, Bag A, for STS 130 there were three (A, B, and C), for STS 131 there were two (A and B), and for STS 132 there were three (A, B, and $\mathrm{C}$ ). From the contents of these bags we deduced they might be trash items that were accumulated before and after docking with the ISS, i.e., between launch and docking with the ISS or between undocking from ISS and before landing. Food items in these bags were mostly snack items rather than the full meal items found in the Volume F trash.

Photos 5, 6, and 7 are all 'footballs' found in the Volume F trash. They were separately placed into plastic-film ziplock bags, and securely wrapped with duct tape. Some had duct tape wrapped around the middle both longitudinally and laterally, while others were completely covered with a layer of duct tape. After opening and examining the contents of a few of these footballs, we could usually differentiate between footballs without opening them. The categories we labeled these footballs were: food (and like items) footballs (Photo 5), MAG (EVA diapers) footballs (Photo 6), and Elbow pack (daily toilet wipes, etc.) footballs (Photo 7). The contents of one Elbow pack football is shown in Photo 8. The food footballs contained heterogenous wastes (non-MAG or Elbow Pack wastes) including drinks, food waste items and packaging, personal hygiene wastes such as wipes, and paper / office items. Photo 9 shows a bin with items we categorized as personal hygiene items, i.e., wipes, and paper, etc., that were removed from a number of food waste (predominantly) footballs. To our knowledge, the only other photodocumentation of Volume $\mathrm{F}$ trash was done by Kish, et al. ${ }^{1}$, and these digital images are still available. The photos of trash from STS 105, taken in 2001, do not appear very different from the trash photos shown here for STS 129. 


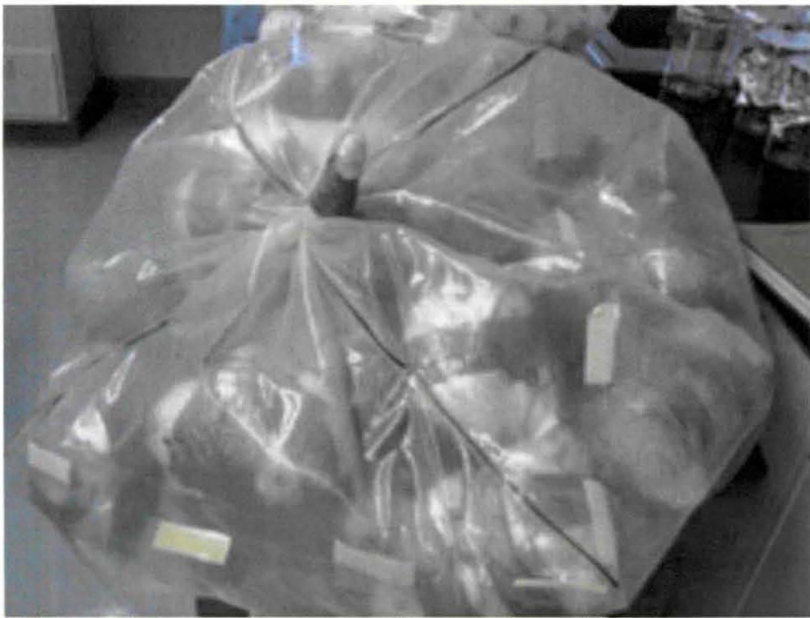

Photo 1. Shuttle Volume F trash.

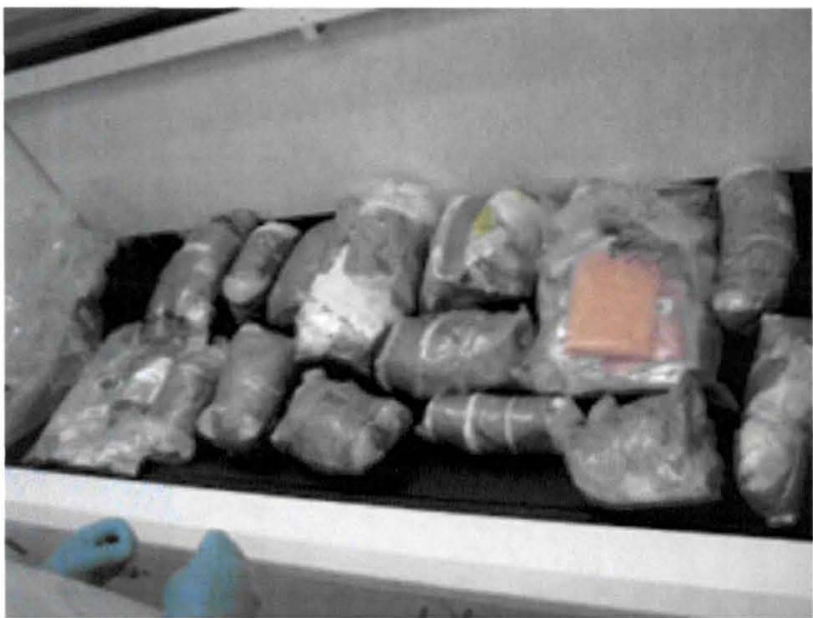

Photo 3. Mixture of different football types prior to cataloging and placing into categories. Footballs are from the Shuttle Volume F trash.

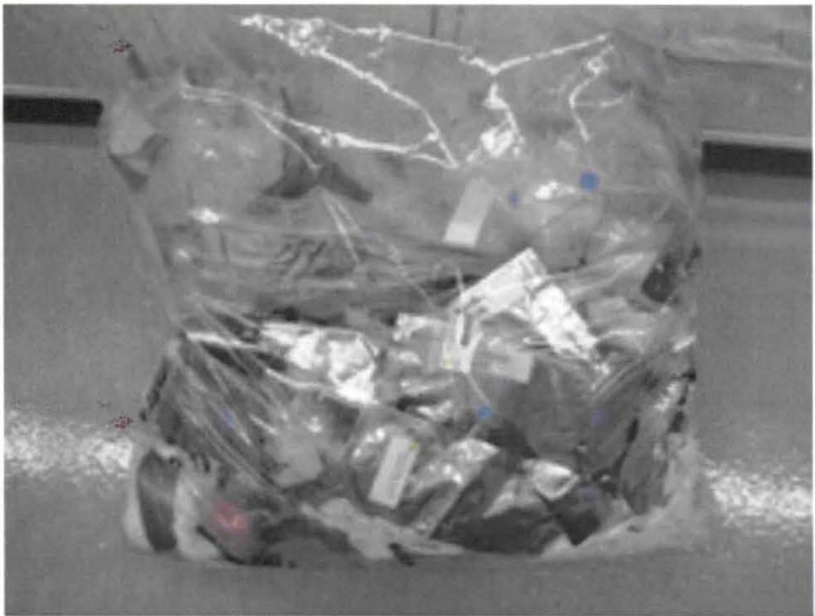

Photo 2. Shuttle trash, not Volume F trash, contained in a large ziplock plastic film bag.

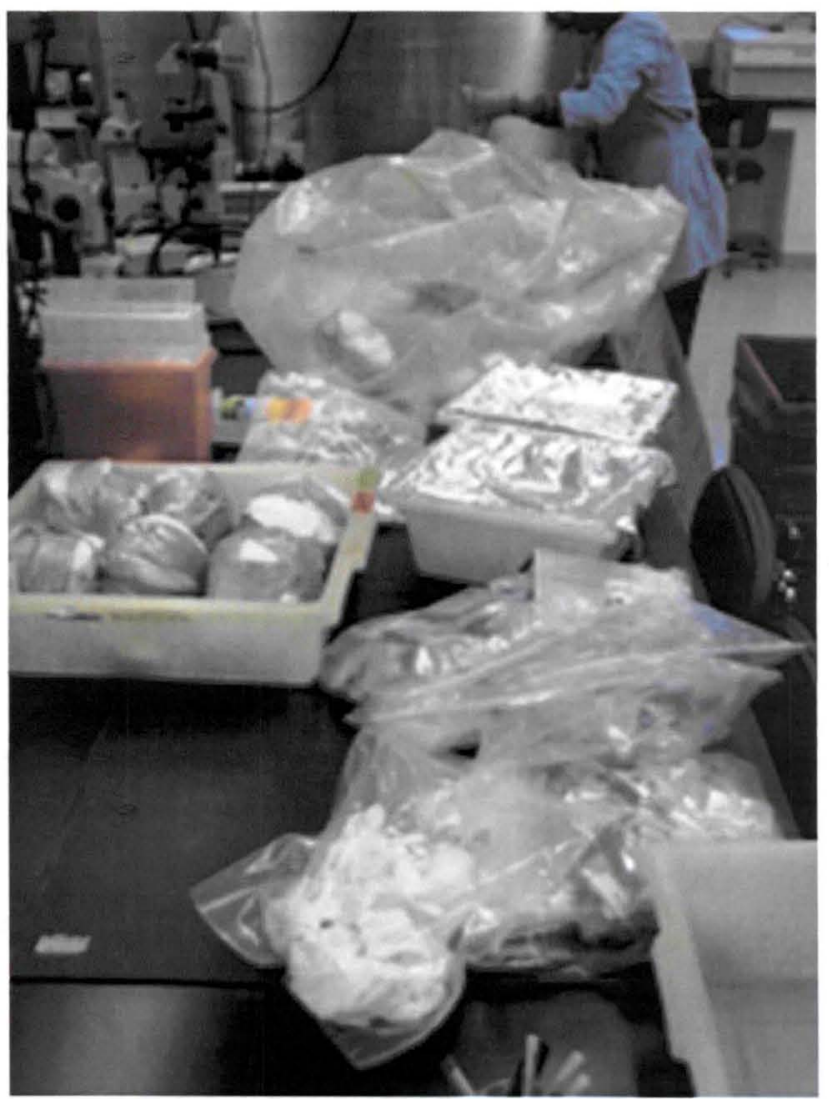

Photo 4. Project personnel cataloging and categorizing football contents. The footballs were from the Shuttle Volume $\mathrm{F}$ trash. 


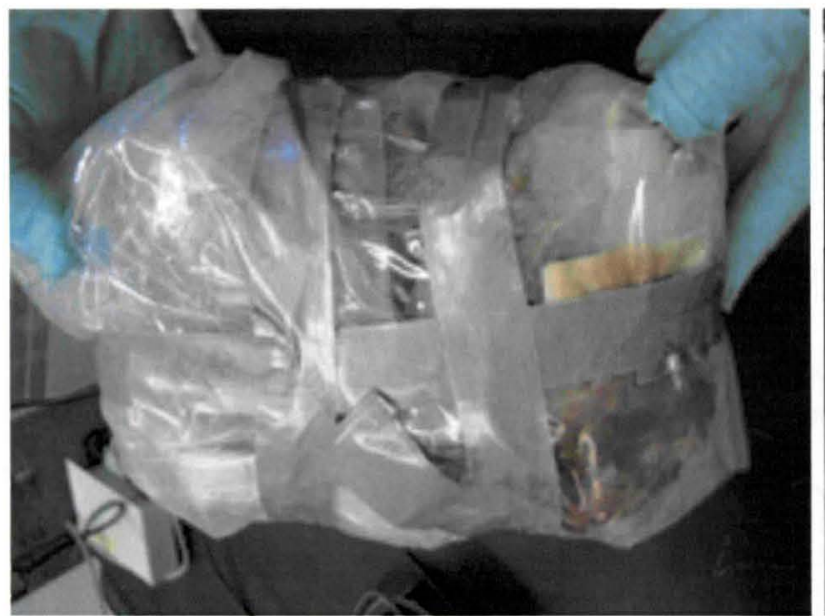

Photo 5. A food 'football' from the Shuttle Volume F trash.

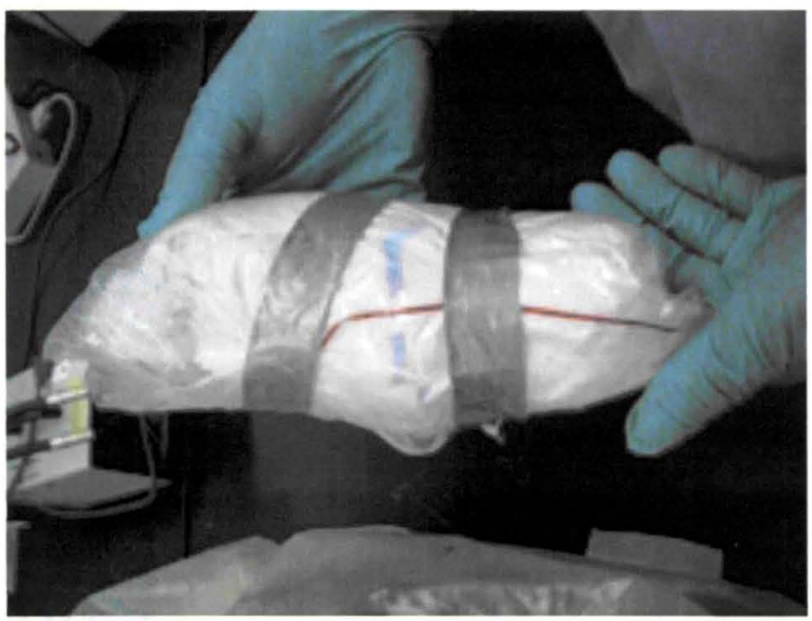

Photo 7. An Elbow pack 'football' from the Shuttle Volume F trash.

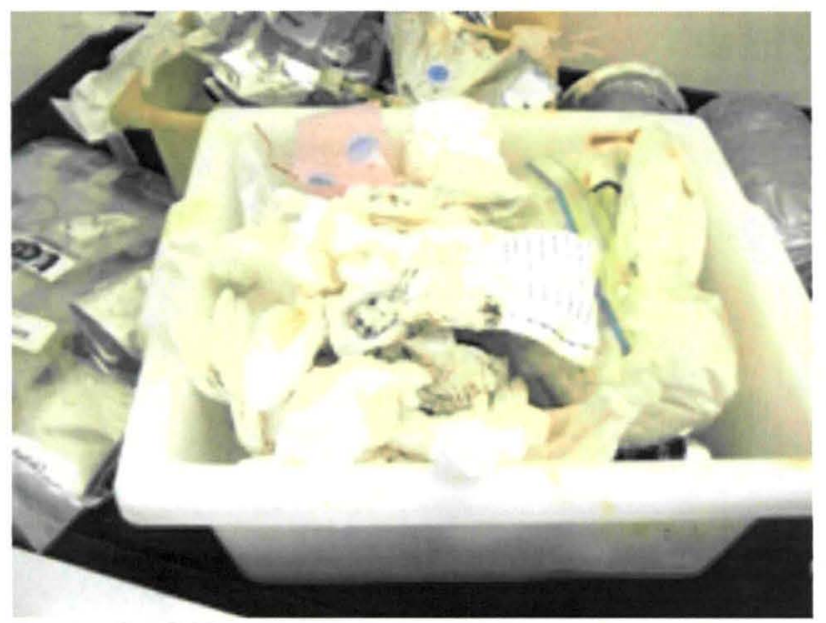

Photo 9. Office trash, e.g., paper, personal hygiene wastes, e.g., wipes, and other waste after separation and categorization. These items were from a food 'football' in the Shuttle Volume F trash.

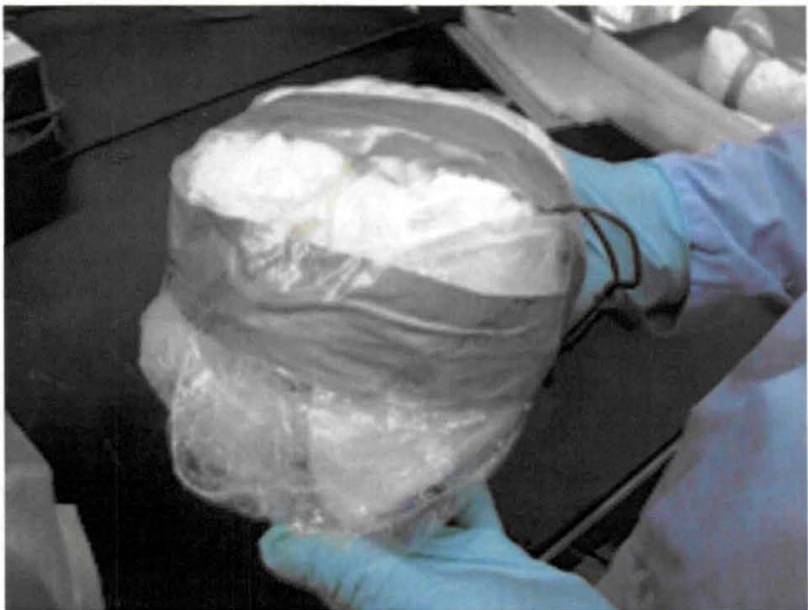

Photo 6. A Maximum Adsorption Garment (MAG, EVA diaper) 'football' from the Shuttle Volume F trash.

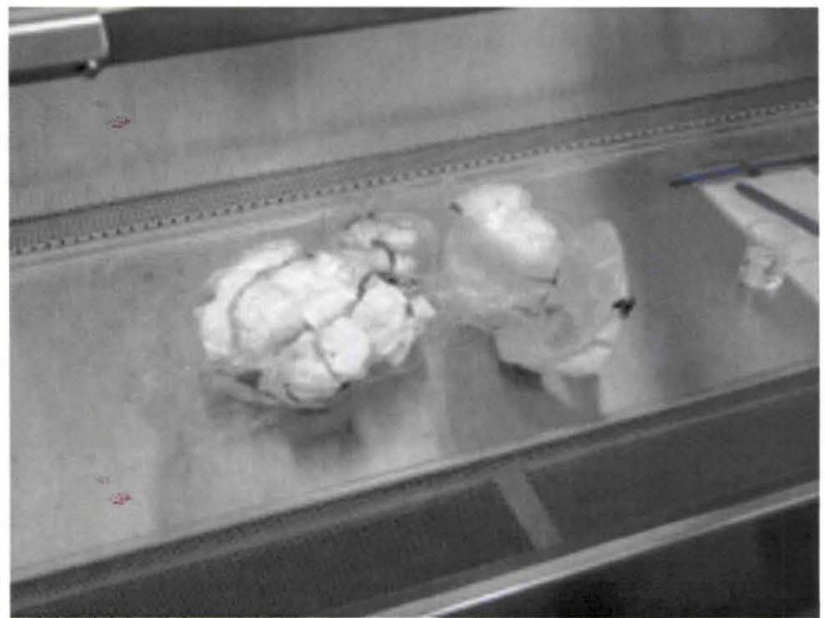

Photo 8. Contents of an Elbow pack 'football' in the Class 2 Biological Hazard Containment laminar flow hood for processing. 
Determination of weight distribution and water content of STS trash by category.

Table 2 is a summary of the trash wet weight and water distribution by STS mission. Because mission duration and crew size should have an effect on the amount of trash generated, the last two columns on the right show the production 'rate', in mass per crew member per day. On this basis, STS 130 had the most trash as well as the most water in the trash. The average production rates for wet trash was $0.60 \mathrm{~kg} \mathrm{crew}^{-1} \mathrm{day}^{-1}$ and water in trash was 0.15 $\mathrm{kg} \mathrm{crew}^{-1} \mathrm{day}^{-1}$. Nearly one quarter of the shuttle trash was water. These data on trash water content should help in the deciding if water recovery from crew trash should be considered. If these data were used to estimate trash amounts for a longer duration mission, for instance, for a crew of 4 over a 180 day mission (e.g., on the lunar surface under some Constellation scenarios) the total amount of trash would be in the range of $430 \mathrm{~kg}$ of total wet waste and $110 \mathrm{~kg}(\sim 110$ liters) of water. Storage disposal of this trash would require a rather large volume. Unfortunately, we did not estimate the volume of the Volume F trash in this study.

\begin{tabular}{|c|c|c|c|c|c|c|c|}
\hline \multirow{2}{*}{$\begin{array}{c}\text { STS } \\
\text { mission }\end{array}$} & \multirow{2}{*}{$\begin{array}{c}\text { Crew } \\
\text { size }\end{array}$} & \multirow{2}{*}{$\begin{array}{l}\text { Mission } \\
\text { duration }\end{array}$} & \multirow{2}{*}{$\begin{array}{c}\text { Total trash } \\
\text { weight }\end{array}$} & \multirow{2}{*}{$\begin{array}{c}\% \\
\text { water }\end{array}$} & \multirow{2}{*}{$\begin{array}{c}\text { Weight of } \\
\text { water }\end{array}$} & \multicolumn{2}{|c|}{ Trash production 'rates' } \\
\hline & & & & & & Total wet wt. & Water in trash \\
\hline & & (days) & $\left(\mathrm{kg}_{\text {wet }}\right)$ & $(\%)$ & $\left(\mathrm{kg}_{\text {water }}\right)$ & $\left(\mathrm{kg}_{\text {wet }} \mathrm{CM}-\mathrm{d}^{-1}\right)$ & $\left(\mathrm{kg}_{\text {water }} \mathrm{CM}-\mathrm{d}^{-1}\right)$ \\
\hline 129 & 6 & 11 & 43.4 & 24.2 & 10.5 & 0.657 & 0.159 \\
\hline 130 & 6 & 14 & 58.3 & 36.2 & 17.2 & 0.693 & 0.204 \\
\hline 131 & 7 & 15 & 52.7 & 36.7 & 19.4 & 0.502 & 0.184 \\
\hline 132 & 6 & 12 & 40.0 & 35.5 & 9.4 & 0.556 & 0.131 \\
\hline \multicolumn{6}{|c|}{ Average, $n=4$} & 0.602 & 0.170 \\
\hline \multicolumn{6}{|c|}{ Standard deviation } & 0.089 & 0.032 \\
\hline
\end{tabular}

The categories that were assigned to waste items during the inventory of trash contents were: (1) Personal Hygiene - which consisted of towels, cleaning supplies, used and unused MAGs, Elbow packs, and wipes; (2) Drink items - which consisted of drink pouches and containers of breakfast drinks, water, fruit drinks, etc.; (3) Food waste including packaging; (4) Office waste and supplies - paper, gloves, tissues; (5) Plastic film - the outer bags of Volume F bag, Bags A, B, and C, and the outer plastic covering of 'footballs' and duct tape; and (6) Miscellaneous, which were silica gel packets for STS 129 only.

Table 3 gives a summary of the wet weight and water distribution by waste category. Personal hygiene wastes made up the largest category of waste at $43 \%$ of the total trash, and also had the highest water content, $69 \%$. In data not shown in this report, the MAGs and the elbow packs contributed the most to personal hygiene wastes in both wet weight and amount of water. Because of the high water absorption capacity of the MAG diaper material, it took nearly a month of drying at $70{ }^{\circ} \mathrm{C}$ to reach a constant weight for the MAGs. If a short processing time for water recovery is important, then this waste may cause problems. The two other waste categories that contained water were the drink items and food items, at $16 \%$ and $19 \%$ of the total trash water and $14 \%$ and $19 \%$ of total waste. 


\begin{tabular}{|c|c|c|c|c|}
\hline Waste category & $\begin{array}{c}\text { Total wet } \\
\text { weight }(\mathrm{kg})\end{array}$ & $\begin{array}{l}\text { Percent of } \\
\text { total trash }\end{array}$ & $\begin{array}{l}\text { Weight of } \\
\text { water }(\mathrm{kg})\end{array}$ & $\begin{array}{l}\text { Percent of } \\
\text { total water }\end{array}$ \\
\hline Personal Hygiene & 84.2 & $49.5 \%$ & 39.5 & $68.7 \%$ \\
\hline Drink items & 26.9 & $15.8 \%$ & 9.2 & $16.1 \%$ \\
\hline Food, incl packaging & 37.3 & $21.9 \%$ & 8.7 & $15.2 \%$ \\
\hline Office waste & 2.7 & $1.6 \%$ & 0.0 & $0.0 \%$ \\
\hline Plastic film & 18.3 & $10.8 \%$ & 0.0 & $0.0 \%$ \\
\hline Misc. & 0.6 & $0.3 \%$ & 0.0 & $0.0 \%$ \\
\hline Shipped to ARC & $(24.4)$ & -- & ND & ND \\
\hline
\end{tabular}

Note: Items from STS 130 and 132 that were shipped to ARC were not categorized and, thus, the weights were not included in the calculations for percent of total trash and percent of total water.

\section{Discussion}

The Advanced Life Support (ALS) Baseline Values and Assumptions Document ${ }^{2}$ (BVAD) provides a good summary and analysis of 'Historical Waste Loads from Space Transportation System Missions' from a number of other documents and manuscripts (Golub and Wydeven ${ }^{3}$, Garcia $^{4}$, Ground ${ }^{5}$, and Maxwell [data published in a Boeing Internal Document]) prior to its publication date in 2004. According to this report the Volume $\mathrm{F}$ wet trash had been characterized for six shuttle missions, but only one of these had visited the ISS. These data were used in the BVAD to provide data for development of a waste model to support the Waste Subsystem analysis within the ALS project. The average amount of trash generated during these missions was $1.39 \mathrm{~kg} \mathrm{CM- \textrm {d } ^ { - 1 }}$ versus the present study where 4 missions averaged less than half of this at $0.60 \mathrm{~kg} \mathrm{CM}-\mathrm{d}^{-1}$. Water content comparisons between studies would be $0.30 \mathrm{~kg} \mathrm{CM}-\mathrm{d}^{-1}$ versus $0.15 \mathrm{~kg} \mathrm{CM}-\mathrm{d}^{-1}$, which is again about half as much.

The most detailed of the studies cited in the BVAD was the one by Golub and Wydeven ${ }^{3}$ for STS 51D which found $49 \mathrm{~kg}$ of total waste, of which $28 \mathrm{~kg}$ was food-related trash. Food plastic packaging and other plastics and paper amounted to almost $47 \%$ of the total trash. Total water content of the trash was only $9.6 \%$. This is the lowest reported amount of water for the Volume F trash in the six STS missions mentioned in the BVAD and the 4 STS missions in the present report.

This report publishes detailed results for waste categories of the Volume F trash and other wastes for STS missions. As Table $4 \mathrm{a}, \mathrm{b}, \mathrm{c}$, and d shows, the contents of trash bags varied between missions, but some trends were noted. Most of the drink pouches were in Bags A, B, and C, $62 \%$ for STS 129, 93\% for STS 30, 82\% for STS 131 , and $88 \%$ for STS 132 when compared with Volume F. Most of the food items were in the Volume F trash - $93 \%$ for STS $129,62 \%$ for STS $130,91 \%$ for STS 131 , and $96 \%$ for STS 132 . Wastes in the personal hygiene category were mostly found in the Volume F trash for STS 129,131 , and $132-88 \%, 97 \%$ and $80 \%$-- but for STS 130 most of the personal hygiene wastes were in Bags A, B, and C. The reason for this waste distribution is not known to us, but it could be that Volume F trash was collected on orbit and the other trash bags - A, B, and C - contained material in transit, i.e., between Earth and orbit. These data also show the importance of dividing wastes into categories before taking samples for microbial characterization or for further treatment for water recovery and/or waste sanitization or sterilization.

Of note is that approximately $30 \%$ of the Volume F wastes from STS 130 (Table 4b) and 34\% of wastes from Bags A, B, C and the Volume F trash from STS 132 were sent to WMS scientists and engineers at ARC for their use as feed material for solid waste processing technologies under development there, such as the Heat Melt Compactor ${ }^{6}$. These wastes will complement their studies which have been conducted to date with model or simulated space mission wet trash.

\section{Conclusion}

The composition of trash returned from four recent STS missions was determined. The trash material was 'Volume F' trash and other trash, in large zip-lock bags, that accompanied the Volume F trash. This report covers 
trash content, weight and water content. A companion report will present data on the microbial characterization of this trash. STS trash was usually made available within 2 days of landing at KSC. The Volume F bag was weighed, opened and the contents were cataloged and placed into one of the following categories: food waste (and containers), drink containers, personal hygiene items - including EVA maximum absorbent garments (MAGs) and Elbow packs (daily toilet wipes, etc), paper, and packaging materials - plastic film and duct tape. Trash generation rates for the four STS missions: Total wet trash was $0.602 \pm 0.089 \mathrm{~kg}_{\text {wet }}$ crew ${ }^{-1} \mathrm{~d}^{-1}$ containing about $25 \%$ water at $0.154 \pm 0.030 \mathrm{~kg}_{\text {water }} \mathrm{crew}^{-1} \mathrm{~d}^{-1}$ (avg \pm stdev). Cataloging by category: personal hygiene wastes accounted for $50 \%$ of the total trash and $69 \%$ of the total water for the four missions; drink items were $16 \%$ of total weight and $16 \%$ water; food wastes were $22 \%$ of total weight and $15 \%$ of the water; office waste and plastic film were $2 \%$ and $11 \%$ of the total waste and did not contain any water. The results can be used by NASA to determine requirements and criteria for Waste Management Systems on future missions.

\section{Appendix}

Table 4 (a, b, c, and d), in the Appendix, shows the contents of individual bags of Shuttle trash that were received by $\mathrm{KSC}$ and included more than the Volume F trash compartment. Additional bags of trash were labeled by us, when we received them, as Bag A, Bag B, and Bag C so we could keep track of the waste source(s). The number of these bags for each mission were: one (Bag A) for STS 129 (Table 4a), three (Bag A, Bag B, and Bag C) for STS 130, two (Bag A, Bag B) for STS 131, and three (Bag A, Bag B, and Bag C) for STS 132. 


\begin{tabular}{|c|c|c|c|c|}
\hline Source & Waste Category & Wet weight $(\mathrm{g})$ & $\%$ moisture & Calculated Water $(\mathrm{g})$ \\
\hline \multirow[t]{7}{*}{ Bag "A" } & Personal Hygiene & 2,673 & $15.5 \%$ & 414 \\
\hline & Drink items & 3,240 & $25.0 \%$ & 810 \\
\hline & Food, including packaging & 700 & $4.4 \%$ & 31 \\
\hline & Office waste & 184 & $0.0 \%$ & - \\
\hline & Plastic film & 2,080 & $0.0 \%$ & - \\
\hline & Misc. & 590 & $0.0 \%$ & - \\
\hline & Subtotal & 9,467 & & 1,255 \\
\hline \multirow[t]{7}{*}{ Volume F } & Personal Hygiene & 18,912 & $27.2 \%$ & 5,136 \\
\hline & Drink items & 2,020 & $45.8 \%$ & 925 \\
\hline & Food, including packaging & 8,902 & $35.5 \%$ & 3,164 \\
\hline & Office waste & 67 & $0.0 \%$ & - \\
\hline & Plastic film & 4,000 & $0.0 \%$ & - \\
\hline & Subtotal & 33,902 & & 9,226 \\
\hline & Grand total & 43,368 & $24.2 \%$ & 10,481 \\
\hline
\end{tabular}




\section{Table $4 \mathrm{~b}$. Weight and moisture distribution of categories of waste in STS 130 trash.}

\begin{tabular}{|c|c|c|c|c|}
\hline Source & Waste Category & Wet weight (g) & $\%$ moisture & Calculated Water (g) \\
\hline Bag A & $\begin{array}{r}\text { Personal Hygiene } \\
\text { Drink items } \\
\text { Food, incl packaging } \\
\text { Office waste } \\
\text { Plastic film } \\
\text { Subtotal } \\
\end{array}$ & $\begin{array}{c}9,888 \\
3,148 \\
928 \\
100 \\
\\
\mathbf{1 4 , 0 6 4} \\
\end{array}$ & $\begin{array}{c}43.8 \% \\
25.4 \% \\
6.0 \%\end{array}$ & $\begin{array}{c}4,332 \\
799 \\
56 \\
\\
\\
\mathbf{5 , 1 8 7} \\
\end{array}$ \\
\hline Bag B & $\begin{array}{r}\text { Personal Hygiene } \\
\text { Drink items } \\
\text { Food, incl packaging } \\
\text { Office waste } \\
\text { Plastic film } \\
\text { Subtotal }\end{array}$ & $\begin{array}{c}4,354 \\
3,239 \\
1,181 \\
40 \\
\\
\mathbf{8 , 8 1 4} \\
\end{array}$ & $\begin{array}{l}28.1 \% \\
28.4 \% \\
16.8 \%\end{array}$ & $\begin{array}{c}1,221 \\
921 \\
199 \\
\\
\mathbf{2 , 3 4 1} \\
\end{array}$ \\
\hline Bag C & $\begin{array}{r}\text { Personal Hygiene } \\
\text { Drink items } \\
\text { Food, incl packaging } \\
\text { Office waste } \\
\text { Plastic film } \\
\text { Subtotal }\end{array}$ & $\begin{array}{c}3,838 \\
798 \\
1,642 \\
- \\
\\
6,278 \\
\end{array}$ & $\begin{array}{c}43.8 \% \\
18.8 \% \\
6.1 \%\end{array}$ & $\begin{array}{c}1,681 \\
150 \\
101 \\
\\
\mathbf{1 , 9 3 2} \\
\end{array}$ \\
\hline \multirow[t]{3}{*}{ Volume F } & $\begin{array}{r}\text { Personal Hygiene } \\
\text { Drink items } \\
\text { Food, incl packaging } \\
\text { Office waste } \\
\text { Plastic film } \\
\text { Shipped to ARC }\end{array}$ & $\begin{array}{c}10,230 \\
557 \\
6,170 \\
- \\
1,240 \\
10,900 \\
\end{array}$ & $\begin{array}{l}60.8 \% \\
54.8 \% \\
18.8 \%\end{array}$ & $\begin{array}{c}6224 \\
305 \\
1,163\end{array}$ \\
\hline & Subtotal & 29,097 & & 7,692 \\
\hline & Grand total & 58,253 & $36.2 \%$ & 1,7152 \\
\hline
\end{tabular}




\begin{tabular}{|c|c|c|c|c|}
\hline Source & Waste Category & Wet weight $(\mathrm{g})$ & $\%$ moisture & Calculated Water $(\mathrm{g})$ \\
\hline Bag A & $\begin{array}{r}\text { Personal Hygiene } \\
\text { Drink items } \\
\text { Food, incl packaging } \\
\text { Office waste } \\
\text { Plastic film } \\
\text { Subtotal }\end{array}$ & $\begin{array}{c}400 \\
3,140 \\
460 \\
640 \\
2,720 \\
7,360 \\
\end{array}$ & $\begin{array}{c}12.3 \% \\
25.6 \% \\
3.9 \%\end{array}$ & $\begin{array}{c}49 \\
803 \\
18 \\
\\
\mathbf{5 , 1 8 7} \\
\end{array}$ \\
\hline Bag B & $\begin{array}{r}\text { Personal Hygiene } \\
\text { Drink items } \\
\text { Food, incl packaging } \\
\text { Office waste } \\
\text { Plastic film } \\
\text { Subtotal } \\
\end{array}$ & $\begin{array}{c}460 \\
3,480 \\
560 \\
460 \\
1,200 \\
6,160 \\
\end{array}$ & $\begin{array}{c}7.3 \% \\
28.3 \% \\
2.3 \%\end{array}$ & $\begin{array}{c}33 \\
984 \\
13 \\
\\
\mathbf{1 , 0 3 1}\end{array}$ \\
\hline Volume F & $\begin{array}{r}\text { Personal Hygiene } \\
\text { Drink items } \\
\text { Food, incl packaging } \\
\text { Office waste } \\
\text { Plastic film } \\
\text { Subtotal } \\
\end{array}$ & $\begin{array}{c}24,680 \\
1,460 \\
10,761 \\
- \\
2,300 \\
39,201 \\
\end{array}$ & $\begin{array}{l}61.6 \% \\
24.8 \% \\
17.7 \%\end{array}$ & $\begin{array}{c}15,193 \\
361 \\
1,909 \\
\\
\\
\mathbf{1 7 , 4 6 3} \\
\end{array}$ \\
\hline & Grand total & 52,721 & $45 \%$ & 23,680 \\
\hline
\end{tabular}


Table 4d. Weight and moisture distribution of categories of waste in STS 132 trash.

\begin{tabular}{|c|c|c|c|c|}
\hline Source & Waste Category & Wet weight (g) & $\%$ moisture & Calculated Water $(\mathrm{g})$ \\
\hline \multirow{7}{*}{ Bag A } & Personal Hygiene & 940 & $33.5 \%$ & 315 \\
\hline & Drink items & 2,260 & $31.6 \%$ & 714 \\
\hline & Food, incl packaging & 120 & $8.2 \%$ & 10 \\
\hline & Office waste & 100 & & \\
\hline & Plastic film & 600 & & \\
\hline & Shipped to ARC & 1,600 & & \\
\hline & Subtotal & 5,620 & $25.8 \%$ & 1,038 \\
\hline \multirow{7}{*}{ Bag B } & Personal Hygiene & 740 & $29.8 \%$ & 221 \\
\hline & Drink items & 1,680 & $36.4 \%$ & 612 \\
\hline & Food, incl packaging & 60 & $51.8 \%$ & 31 \\
\hline & Office waste & 340 & & \\
\hline & Plastic film & 560 & & \\
\hline & Shipped to ARC & 1,545 & & \\
\hline & Subtotal & 4,925 & $25.6 \%$ & 864 \\
\hline \multirow{7}{*}{ Bag C } & Personal Hygiene & 40 & & - \\
\hline & Drink items & 1,180 & $43.9 \%$ & 517 \\
\hline & Food, incl packaging & 60 & & - \\
\hline & Office waste & 720 & & \\
\hline & Plastic film & 2,000 & & \\
\hline & Shipped to ARC & 2,182 & & \\
\hline & Subtotal & 6,182 & $12.9 \%$ & 517 \\
\hline \multirow{8}{*}{ Volume F } & Personal Hygiene & 7,080 & $66.7 \%$ & 4,720 \\
\hline & Drink items & 720 & $33.9 \%$ & 244 \\
\hline & Food, incl packaging & 5,738 & $35.8 \%$ & 2,055 \\
\hline & Office waste & 20 & & \\
\hline & Plastic film & 1,620 & & \\
\hline & Shipped to ARC & 8,136 & & \\
\hline & Subtotal & 23,314 & $46.2 \%$ & 7,020 \\
\hline & Grand total & 40,042 & $23.6 \%$ & 9,439 \\
\hline
\end{tabular}




\section{Acknowledgments}

The research reported in this paper was supported by NASA Exploration Life Support (currently named Life Support and Habitation Systems) project through the Waste Management System element.

\section{References}

${ }^{1}$ Kish, A. L., Hummerick, M. P., Roberts, M. S., Garland, J. L., Maxwell, S., Mills, A. "Biostability and Microbiological Analysis of Shuttle Crew Refuse," SAE Tech Rep. 2002-01-2356, 2002.

${ }^{2}$ Hanford, A. J., "Advanced Life Support Baseline Values and Assumptions Document," CTSD-ADV-484 A, National Aeronautics and Space Administration, Lyndon B. Johnson Space Center, Houston, Texas. 2004.

${ }^{3}$ Wydeven, T., and Golub, M. A., (1991) "Waste Streams in a Crewed Space Habitat," Waste Management and Research Vol. 9, pp. 91-101, 1991.

${ }^{4}$ Garcia, R. "Space Transportation System 29 (STS-29) Trash Evaluation Final Report", JSC-SP-89-1, National Aeronautics and Space Administration, Lyndon B. Johnson Space Center, Houston, Texas. 1989.

${ }^{5}$ Grounds, P. "Space Transportation System 35 (STS-35) Trash Evaluation Final Report", JSC-SP-90-2, National Aeronautics and Space Administration, Lyndon B. Johnson Space Center, Houston, Texas. 1990.

${ }^{6}$ Pace, G.S., and Fisher, J., "Testing and Analysis of the First Plastic Melt Waste Compactor Prototype," SAE Tech Rep. 2005-01-3080, 2005. 